\title{
Uma área de relevante interesse biológico, porém pouco conhecida: a Reserva Florestal do Morro Grande
}

\author{
Jean Paul Metzger ${ }^{1}$, Luciana F. Alves ${ }^{2}$, William Goulart ${ }^{1}$, Ana Maria de Godoy Teixeira', Sílvio Jorge C. Simões ${ }^{3}$ \& \\ Eduardo Luís Martins Catharino ${ }^{2}$
}

Biota Neotropica v6 (n2)-http://www.biotaneotropica.org.br/v6n2/pt/abstract?article+bn00206022006

\author{
Recebido em 17/11/2004. \\ Versão reformulada recebida em 25/08/2005. \\ Publicado em 01/05/2006
}
${ }^{1}$ Departamento de Ecologia, Instituto de Biociências, Universidade de São Paulo, Rua do Matão, 321, travessa 14, 05508-900 São Paulo, SP (autor para correspondência: jpm@ib.usp.br)
${ }^{2}$ Instituto de Botânica, Seção de Ecologia, Caixa Postal 4005, 01061-970 São Paulo, SP
${ }^{3}$ Departamento de Engenharia Civil, Universidade Estadual Paulista - UNESP, Campus de Guaratinguetá,
Caixa Postal 205, 12516-410 Guaratinguetá, SP

\begin{abstract}
Metzger, J.P.; Alves. L.F.; Goulart, W.; Teixeira, A.M.G.; Simões, S.J.C. \& Catharino, E.L. An important biological area, but still poorly known: the Morro Grande Forest Reserve. Biota Neotrop. May/Aug 2006 vol. 6 no. 2, http:// www.biotaneotropica.org.br/v6n2/pt/abstract?article+bn00206022006. ISSN 1676-0603
\end{abstract}

The Morro Grande Forest Reserve (10,870 ha) is one of the biggest forest areas in the Atlantic Plateau. This region was intensively deforested for agriculture, wood and charcoal production, and more recently by the expansion of urban areas. The Reserve is located in the cristalline Plateau of Ibiúna, just above the Paranapiacaba Mountain (860 - 1075 m above sea level), in a transition region between the rainy climate from the Atlantic coast, and the seasonal climate from inland São Paulo state. As a consequence, species composition in Morro Grande Reserve combines elements from the tropical rainforest and the semideciduous forest. Despite this particularity, few studies were carried out in the forests from Morro Grande. It is only in 2000 that a group of scientist related to the BIOTA/FAPESP program began a systematic analysis of the species composition of different taxonomic groups, as well as the analysis of ecological processes related with forest regeneration. The present manuscript introduces a series of nine articles with the biological data obtained in the Reserve these last four years, and aims also to present an historical and abiotic description of the Reserve, highlighting aspects of the relief, geologic and pedological conditions, climate, hydrography, land use and land cover.

Key words: Morro Grande Forest Reserve, Atlantic Forest, relief, geologic and pedological conditions, climate, hydrography, land use and land cover

\section{Resumo}

Metzger, J.P.; Alves. L.F.; Goulart, W.; Teixeira, A.M.G.; Simões, S.J.C. \& Catharino, E.L. Uma área de relevante interesse biológico, porém pouco conhecida: a Reserva Florestal do Morro Grande. Biota Neotrop. May/Aug 2006 vol. 6 no. 2 , http://www.biotaneotropica.org.br/v6n2/pt/abstract?article+bn00206022006. ISSN 1676-0603

A Reserva Florestal do Morro Grande (RFMG, 10.870 ha) é um dos maiores remanescentes florestais do Planalto Atlântico paulista, região que foi submetida a fortes pressões de desmatamento tanto para a agricultura quanto para a exploração da lenha e do carvão e, mais recentemente, para a expansão imobiliária. A RFMG situa-se sobre embasamento cristalino, justo acima da Serra de Paranapiacaba, em altitudes que variam de 860 a 1075 m, numa região de transição entre o clima pluvial tropical do litoral e da encosta Atlântica, com o clima estacional do interior do estado. Por conseguinte, suas florestas acabam tendo uma composição de espécies particular, com elementos das florestas ombrófila densa e mesófila semi-decidual. Apesar desta particularidade, não houve até recentemente praticamente nenhum estudo nas florestas do Morro Grande. Foi apenas a partir de 2000 que um grupo de pesquisadores, no contexto de um projeto temático vinculado ao programa BIOTA/FAPESP, procurou analisar de forma sistemática a composição de diferentes grupos taxonômicos, assim como caracterizar processos ecológicos associados com a regeneração florestal. Este artigo tem por objetivo introduzir uma série de nove artigos com os principais resultados dos levantamentos biológicos na RFMG, obtidos nos últimos quatro anos, assim como fazer uma caracterização do histórico e das condições abióticas na Reserva, em termos de embasamento geológico, pedológico, clima, hidrografia, e do uso e cobertura do território.

Palavras-chave: Reserva Florestal do Morro Grande, Mata Atlântica, embasamento geológico, pedológico, clima, hidrografia, uso e cobertura do território 


\section{Introdução}

Apesar de ser uma das últimas áreas de Mata Atlântica de grande extensão localizada no Planalto Atlântico Paulistano e de sua proximidade com a cidade de São Paulo e seus centros pesquisas, a Reserva Florestal do Morro Grande (RFMG) era pouco conhecida do ponto de vista biológico até o ano de 2000. Com exceção de um estudo com abelhas (Aguilar 1998), todos os demais levantamentos na RFMG existentes até então tinham como foco os corpos d’água (Tundisi 1991, Brega 1995, SABESP 1997), praticamente ignorando a área florestal. Este viés está diretamente relacionado com o histórico da Reserva, fortemente ligado à questão do abastecimento de água e da própria administração da Reserva, que está a cargo da SABESP (Companhia de Saneamento Básico do Estado de São Paulo). A presença da floresta sempre foi encarada como uma maneira de evitar a poluição, eutrofização e assoreamento dos corpos d’água, mas não como o objeto central da conservação.

Assim, o Morro Grande permaneceu praticamente desconhecido nas suas áreas terrestres, contrariamente a outras áreas próximas localizadas no Planalto Atlântico, como a Serra da Cantareira, muito estudada por pesquisadores do Instituto Florestal, ou a Serra do Japi (Morellato 1992). Foi apenas recentemente que um grupo interdisciplinar de pesquisadores, no âmbito do Programa BIOTA/FAPESP (www.biota.org.br), decidiu estudar de forma sistematizada as florestas do Morro Grande (projeto Conservação da Biodiversidade em Paisagens Fragmentadas no Planalto Atlântico de São Paulo, coordenado por Jean Paul Metzger). Ao longo de cinco anos, de 2000 a 2005, uma equipe de cerca de 20 pesquisadores e 25 estudantes obteve dados sobre diferentes grupos taxonômicos e processos ecológicos no Morro Grande. Parte destes dados já está publicada, como no caso dos levantamentos de borboletas (Uehara-Prado et al. 2004) ou dos estudos de alometria de plântulas de espécies arbóreas (Portela \& Santos 2003). Estes inventários mostram que a Reserva, apesar de sua proximidade com grandes centros urbanos e de todos os impactos que vem recebendo, ainda mantém uma flora e fauna muito rica, incluindo diversas espécies endêmicas da Mata Atlântica e/ou ameaçadas de extinção. Para a surpresa do grupo de pesquisadores, os levantamentos realizados permitiram registrar as primeiras ocorrências de algumas espécies no estado de São Paulo, assim como a identificação de quatro espécies novas. Dados preliminares do grupo de pesquisadores já permitiram, em agosto de 1999, a inclusão do Morro Grande entre as áreas de "extrema importância biológica” pelo Workshop “Avaliações e ações prioritárias para a conservação da biodiversidade da Mata Atlântica e campos sulinos" (MMA 2000).
Da quase ausência de informação, o Morro Grande possui hoje um conjunto de dados que poucas Unidades de Conservação têm o privilégio de ter. Foram feitos levantamentos detalhados em treze diferentes áreas de florestas secundárias e maduras sobre as comunidades de árvores (Catharino et al. 2006), plântulas (Alves \& Metzger 2006), grandes mamíferos (Negrão \& Valladares-Pádua 2006) e pequenos mamíferos (Pardini \& Umetsu 2006), aves (Develey \& Martensen 2006), répteis e anfíbios (Dixo \& Verdade 2006), e aranhas orbitelas (Nogueira et al. 2006). Pelo fato destes estudos terem sido feitos de forma sistematizada, em locais pré-definidos e ao longo do mesmo intervalo de tempo, será possível analisar e comparar os padrões de riqueza e composição observados para as diferentes comunidades, fornecendo bases mais seguras para o manejo e conservação da Reserva (Metzger et al. 2006). É importante lembrar que a categoria de Reserva Florestal é temporária e que será necessário enquadrar a Reserva Florestal do Morro Grande em umas das categorias do Sistema Nacional de Unidades de Conservação (SNUC, Lei No 9.985, de 18 de Julho de 2000). Os dados biológicos obtidos deverão ser de grande auxílio nesta decisão.

O principal objetivo desta série de artigos é de disponibilizar o conjunto de informação obtido ao longo dos últimos quatro anos, tanto pelo interesse biológico dos dados, quanto pela possibilidade deles subsidiarem o manejo da Reserva. Este primeiro artigo, além de introduzir a série de artigos, visa também caracterizar a Reserva Florestal do Morro Grande em relação ao seu histórico de uso e às suas características abióticas, em termo de clima, embasamento geológico, relevo, solo, hidrografia e uso e cobertura do território.

\section{A área de estudo}

\section{Localização e status de conservação}

A Reserva Florestal do Morro Grande abrange uma área de cerca de 10.870 ha do município de Cotia, SP

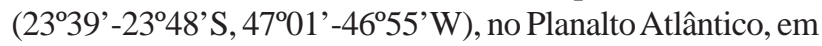
altitudes que variam de 860 a 1075 m.s.m. Situada a 34 km do marco zero da capital do estado, a RFMG é adjacente a leste com o município de Itapecerica da Serra, ao sul com São Lourenço da Serra, a sudoeste com Ibiúna e a noroeste com Vargem Grande Paulista (Figura 1). Os limites da RFMG coincidem com os da bacia do rio Cotia no seu trecho superior, dentro da bacia do Alto-Tietê. Limita-se, assim, a leste com a bacia do Guarapiranga (rio Pinheiros), ao sul, nos contrafortes mais altos, com as cabeceiras do Rio Ribeira de Iguape, em particular com o alto curso do rio São Lourenço, e ao sudoeste com os principais afluentes do rio Sorocaba, os rios Sorocamirim e Sorocabuçu (Figura 2). Pode-se entendê-la como um pequeno anfiteatro nos 
rebordos da Serra do Mar voltado para a bacia de São Paulo, sobre o antigo complexo cristalino do Planalto Atlântico (Catharino et al. 2004).

A principal via de acesso a partir da Capital é a Rodovia Raposo Tavares. No entorno da RFMG localiza-se ainda a Rodovia Régis Bittencourt e o Rodoanel Mário Covas. Um trecho da Estrada de Ferro Sorocabana - Ligação Ferroviária Mairinque-Santos - corta, desde 1937, a região sul da RFMG, enquanto que uma linha do sistema de transmissão de energia elétrica proveniente da hidroelétrica de Itaipú, construída nos anos oitenta, atravessa a RFMG a sudoeste do Reservatório Pedro Beicht (Catharino et al. 2004).

A Reserva contém o Sistema Produtor do Alto-Cotia, gerenciado pela SABESP, composto essencialmente por duas barragens (Pedro Beicht e Cachoeira da Graça), estação de tratamento e laboratórios de controle. Este sistema fornece água para cerca de 400-500 mil habitantes da Grande São Paulo.

A Reserva Florestal do Morro Grande foi criada através da Lei Estadual n. 1.949 de 04 de Abril de 1979, com a destinação específica de preservação da flora e da fauna e proteção aos mananciais. No entanto, a proteção das florestas situadas nas cabeceiras do rio Cotia remonta ao início do século XX, quando os problemas de seca no planalto paulista nos anos 1910 e a poluição do rio Tietê, levaram à decisão de se utilizar as águas da bacia do Cotia para abastecimento da população da cidade de São Paulo (SABESP 1997). Aliada à construção da Barragem "Cachoeira da Graça” (1914-1917) e posteriormente, a montante, da barragem "Pedro Beicht" (1927-1933), houve a desapropriação de antigas fazendas situadas na bacia de captação. A interrupção das atividades agro-pastoris permitiu a regeneração de antigas áreas de pastagem e cultivo. Dessa forma, a Reserva é atualmente composta por um mosaico de florestas secundárias (sensu Brown \& Lugo 1990) em diferentes estádios de sucessão, algumas com aproximadamente 70-80 anos de regeneração, e outras mais antigas e bem estruturadas, provavelmente por não terem sido submetidas ao corte raso na época que ainda existiam fazendas no seu interior. A cobertura florestal predominante do Morro Grande é a Floresta Ombrófila Densa Montana (Veloso et al. 1991), com contribuições da Floresta Estacional Semidecidual e das florestas mistas com Araucária, todas pertencentes ao Domínio da Mata Atlântica.

Ao fazer limite, ao sul, com as cabeceiras do Rio Ribeira de Iguape, as florestas do Morro Grande se interligam com as extensas florestas desta bacia (Figura 3), estendendo-se até o Parque Estadual de Jurupará e estabelecendo ligações mais tênues, pois interrompidas pela Rodovia Regis Bittencourt, com o Parque Estadual da Serra do Mar (Núcleo Curucutu) e a APA Capivari Monos pelos divisores da bacia do Guarapiranga e Ribeira de Iguape. A RFMG representa uma das maiores extensões de florestas contínuas remanescentes no Planalto
Paulistano, uma região de transição climática, geomorfológica e vegetacional, como veremos adiante.

Além da proteção por Lei Estadual, em 1979, dois anos mais tarde, em 1981, foi assinada a Resolução n ${ }^{\circ} 2$ de tombamento da RFMG pela Secretaria da Cultura do Governo do Estado de São Paulo, que a considerou “ecossistema digno de ser preservado quanto à sua cobertura florística, à fauna e aos seus mananciais, além de suas condições paisagísticas, topográficas e valores climáticos, constituindo conjunto de inegável interesse cultural e turístico do Estado de São Paulo”. A partir desta data, a RFMG não poderia ser mais alterada sem prévia autorização do CONDEPHAAT (Conselho de Defesa do Patrimônio Histórico, Arqueológico, Artístico e Turístico do Estado). O tombamento teve com destinação específica a preservação do ambiente natural quanto à sua flora, fauna e proteção dos mananciais. Foram excluídas do tombamento as casas e instalações técnicas existentes. Em 1994, a RFMG foi também inserida como área núcleo na Reserva da Biosfera do Cinturão Verde da Cidade de São Paulo (Figura 4), recebendo assim o reconhecimento internacional da UNESCO (Organização das Nações Unidas para Educação, Ciência e Cultura) pelos significativos serviços ambientais que ela propicia à cidade de São Paulo (Victor et al. 1998).

A competência administrativa sobre as Reservas Florestais estaduais cabe, a princípio, ao Instituto Florestal (IF). No caso do Morro Grande, por ser a SABESP a principal responsável pelo gerenciamento dos reservatórios Pedro Beicht e Cachoeira da Graça, e pela distribuição da água deste manancial, a administração direta, guarda e vigilância da Reserva como um todo está também a seu encargo (Brega Filho \& Bombonato Jr. 1992).

Ressalta-se, no entanto, que as Reservas Florestais são consideradas hoje como uma categoria de manejo provisória, que têm por objetivo a proteção dos recursos naturais para uso futuro e o impedimento de atividades de desenvolvimento até que se defina em qual das categorias existentes a área deve ser enquadrada. Após a aprovação e regulamentação da Lei do Sistema Nacional de Unidades de Conservação da Natureza (SNUC, Lei No 9.985 de 18 de Julho de 2000), tornou-se necessário o enquadramento da RFMG ao conteúdo desta lei.

\section{Histórico da região}

As florestas da região do rio Cotia vêm sendo manejadas desde antes da colonização do Brasil, quando da ocupação pelos índios Carijós (SABESP 1997). No entanto, desmatamentos mais extensos só vieram a ocorrer depois, principalmente a partir do século XVII (Dean 1995). Nesta época, a ocupação do território paulista seguia as bandeiras, que à procura de ouro, pedras preciosas e mão de obra indígena para trabalho escravo, propiciavam o estabelecimento de vilas. A região de Cotia era então utilizada como via de acesso entre 
São Paulo, Sorocaba e Itu. Neste caminho, foi fundada em 1723 a Freguesia de Nossa Senhora do Monte Serrat de Cotia, elevada a Vila em 1856 e a município em 1906.

No início do século XX, a região da bacia do Rio Cotia era chamada de "cinturão caipira” da cidade de São Paulo. Predominavam propriedades agrícolas de médio porte (60-240 ha), pertencentes em grande parte a luso-brasileiros, onde o sistema de cultivo era a agricultura itinerante (Seabra 1971). Cultivava-se principalmente milho, feijão e batata, mas as áreas agrícolas representavam menos de $10 \%$ das terras. Boa parte das terras (ca. 60\%) era mantida sob forma de capoeiras (terras em pousio para agricultura) ou então como áreas de pastagem, cujo porte médio dos rebanhos era de 25 a 100 cabeças por propriedade (SABESP 1997). Estas atividades de subsistência (ditas “caipiras”) foram pouco a pouco abandonadas, em particular com a chegada dos estrangeiros (italianos, portugueses, espanhóis e, principalmente, japoneses) e a implantação de culturas comerciais mais extensas, voltadas para abastecer as cidades de São Paulo, Rio de Janeiro e Santos. O cinturão caipira foi então substituído por um “cinturão hortifrutigranjeiro”, com plantações de tomate, batata, ovos, alcachofra, criação de frango, entre outros, segundo dados da Cooperativa Agrícola de Cotia (Teixeira 2005). Neste mesmo período, houve também uma "proletarização" da região, com o aluguel, por parte dos grandes proprietários (e.g., japoneses), de terras para famílias que haviam perdido suas próprias culturas com a decadência das atividades de subsistência. Em conseqüência da intensificação agrícola, tanto por atividades comerciais quanto pela excessiva sub-divisão das terras, e do conseqüente desgaste dos solos, houve uma expansão das atividades de produção de lenha e carvão vegetal, consideradas então como uma alternativa econômica pelos proprietários.

As décadas de 30 e 40 do século XX impulsionaram sobremaneira a utilização de recursos florestais no entorno da região da cidade de São Paulo, devido ao crescimento urbano e às restrições comerciais e à crise no abastecimento de produtos petrolíferos impostas pela Segunda Guerra Mundial. Neste período ocorreu também a construção da Estrada de Ferro Sorocabana - Ligação Ferroviária Mairinque-Santos (1927-1937), que corta a parte sul da RFMG, facilitando o escoamento do carvão produzido na região. Grande parte das florestas atuais da região de Cotia estabeleceu-se após um período de extração de madeira para combustível, há aproximadamente 50-60 anos atrás (Seabra 1971). Algumas áreas foram completamente devastadas, outras foram abandonadas após intensa perturbação e algumas manchas de floresta permaneceram relativamente pouco perturbadas, principalmente em regiões mais altas, nos topos de morros e ao longo dos rios. A preservação de uma extensa área de floresta muito próxima à Região Metropolitana de São Paulo RMSP só foi possível devido à necessidade de garantir o abastecimento de água à população da capital no início do século XX. A flora e a fauna só vieram a ser consideradas como relevantes para justificar a conservação desta região em 1979, quando da criação por lei da Reserva. Em função do seu histórico de perturbação anterior a 1930, a RFMG pode ser considerada como um grande mosaico de florestas em diferentes estádios sucessionais.

\section{Métodos}

A caracterização do meio físico baseou-se, em parte, na compilação de dados secundários, em geral obtidos em escalas mais grosseiras, e em levantamentos mais detalhados de campo, envolvendo aspectos de cobertura geológica, formações superficiais, relevo e do uso e cobertura do território.

\section{Clima}

Dentro da Reserva Florestal do Morro Grande, há dois postos pluviométricos, um situado na represa de Pedro Beicht (900 m altitude, 23⒋' S/46 ${ }^{\circ} 57^{\prime} \mathrm{W}$ ) e outro na Cachoeira da Graça (850 m de altitude, 2339S e 465' $\mathrm{W}$ ), que permitem retratar o regime pluviométrico da Reserva desde 1915(Setzer 1946, 1949, SABESP 1997). Infelizmente, estes postos deixaram de registrar as temperaturas a partir de 1941, dificultando assim uma caracterização mais completa do clima dentro da Reserva. Para nos auxiliar nesta caracterização, utilizamos os dados meteorológicos referente ao município vizinho de Ibiúna, fornecidos pelo CIIAGRO/ IAC (www.iac.sp.gov.br), por ser o dado recente mais completo e próximo da Reserva.

\section{Caracterização geológica}

A sistemática adotada para o levantamento de dados geológicos consistiu na combinação de estudos de campo (perfis pilotos) com informações obtidas em mapas e levantamentos geológicos e geotécnicos previamente executados na região de estudo e adjacências.

Considerando-se os levantamentos de cunho mais regional, em pequena escala, foi utilizado o mapa geológico do Estado de São Paulo em escala 1:500.00 (Almeida et al. 1981). Trabalhos geológicos que envolvem mais diretamente a Região Metropolitana de São Paulo (RMSP) e a região de Caucaia e adjacências também foram levantados. Em que pese a importância e complexidade da RMSP, os levantamentos geológicos e geotécnicos existentes para esta região são escassos. O principal registro cartográfico é o mapeamento em escala 1:100.000, executado pela EMPLASA, em 1980.

Para a região de estudo, o mapeamento geológico mais detalhado foi realizado para a Folha São Roque, em escala 1:100.000 (Hasui 1975). Para as regiões adjacentes folhas de Santana de Parnaíba e Guarulhos - um mapeamento 
geológico foi executado por Carneiro (1983), no âmbito de sua tese de doutorado. Este autor estudou, principalmente, as características litológicas e a estruturação do Grupo São Roque, o qual não ocorre na área do projeto.

No levantamento geológico de campo foi possível extrair informações acerca de diferentes litologias (tipos de rochas) e estruturas, bem como coletar amostras para análise petrográfica em escala macroscópica.

Devido à profunda alteração intempérica nessa região, não são freqüentes exposições de rochas sãs ou semialteradas e não existem, tampouco, afloramentos contínuos por grandes extensões. Este aspecto constitui um obstáculo para o melhor entendimento das rochas e das estruturas, tanto do ponto de vista da observação individual dos afloramentos quanto das correlações entre exposições diferentes.

A maior parte das observações foi feita em solos estruturados, particularmente quando se encontram as rochas metamórficas menos resistentes ao intemperismo. Através de uma série de comparações, foi possível esboçar os contatos geológicos e estabelecer os aspectos geométricos essenciais.

\section{Relevo}

Para a caracterização regional do relevo, devido à ausência de mapeamentos detalhados na região, foram utilizados os Mapas Geomorfológicos do Estado de São Paulo nas escalas 1:1.000.000 (Ponçano et al. 1981) e 1:500.000 (Ross \& Moroz 1997).

Em escala local, as principais informações morfométricas do relevo da região foram analisadas a partir de cartas topográficas 1:10.000 da EMPLASA (Empresa Metropolitana de Planejamento da Grande São Paulo S.A.; Folhas Represa Pedro Beicht, Itapecerica da Serra, Tijuco Preto e Caraguatá) e da Secretaria de Economia e Planejamento do Governo do estado (SEP; Grilos, Bairro das Brotas), que recobrem a área em estudo. Estas cartas estão baseadas em recobrimento fotográfico de Julho de 1980 e Agosto de 1981, no caso da EMPLASA, e de 1978, no caso da SEP. As cartas foram digitalizadas com um scanner A0 e editadas no programa ArcView ${ }^{\mathrm{TM}} 8.3$ de forma a identificar as curvas de nível, de 5 em 5 metros, obtendo-se, a partir da aplicação do algoritmo "facetas triangulares” (Triangular Irregular Network, TIN) um Modelo Numérico do Terreno. A partir deste modelo, foram gerados os mapas de hipsometria, declividade e orientação de vertente.

\section{Formações superficiais}

A caracterização da cobertura pedológica regional foi baseada nos levantamentos e mapeamentos de Oliveira et al. (1999), obtidos na escala de 1/500.000. Este mapeamento está baseado no novo sistema de classificação da EMBRAPA (1999).
Para o levantamento dos dados de campo relacionados às formações superficiais, foram percorridas as principais estradas e realizados alguns perfis ao longo de drenagens e picadas. A distribuição dos pontos de coleta foi planejada com base em elementos do relevo e informações geológicas preliminares, permitindo a composição de um mosaico de pontos que cobriu a área de estudo. Nestes perfis pilotos foram descritos, detalhadamente, diversos pontos situados em diferentes posições em relação à encosta (topo, meia encosta superior, meia encosta inferior, base). Ao todo, foram descritos, no Morro Grande e adjacências, quatro perfis de relevo e vinte e oito perfis verticais de solo, com amostragem de todos os horizontes identificados no campo.

Em cada perfil vertical, foram coletadas amostras para cada horizonte de solo observado. O princípio básico de diferenciação dos horizontes foi a observação da cor do solo, textura, granulometria e estrutura.

Para descrição e coleta de amostras de solo, foi utilizado o material convencional: martelo pedológico, faca, pá reta, pá de jardineiro, fita métrica, etiqueta e saco para embalagem de amostras. Em alguns casos específicos, foi feita sondagem com trado helicoidal, de um metro de comprimento e $2 \mathrm{~cm}$ de diâmetro, o qual contribuiu para complementar as informações provenientes da superfície.

\section{Uso e cobertura do território}

\subsection{Mapeamento do uso e cobertura do território a partir de imagens de satélite}

Para o mapeamento de uso e cobertura do território da Reserva Florestal do Morro Grande e de uma faixa de $10 \mathrm{~km}$ de largura no entorno da mesma, foram utilizadas duas imagens do satélite LANDSAT-7 (órbita/ponto 219/76 e 219/77), obtidas em Abril de 2000. Uma classificação supervisionada preliminar foi elaborada a partir das bandas 1 (azul), 2 (verde), 3 (vermelho), 4 (infravermelho próximo), 5 (infravermelho médio) e 7 (infravermelho longo) do sensor Enhanced Thematic Mapper (ETM+), todas com resolução de 30 metros. As bandas 6 e pancromática não foram utilizadas neste trabalho por considerar-se que não forneciam informação espectral útil aos objetivos deste mapeamento. As áreas de treinamento foram amostradas dentro da Reserva Florestal do Morro Grande e em seu entorno. A classificação, executada no programa ERDAS IMAGINE ${ }^{\mathrm{TM}} \mathrm{V} .8 .4$, foi baseada no método de máxima verossimilhança (Crosta 1992).

As classes escolhidas para a composição do mapa foram: agricultura, área urbana, campo ou área degradada, vegetação em estádios de sucessão iniciais, vegetação em estádios de sucessão médios e avançados e corpos d’água. Os mapeamentos obtidos foram sistematicamente conferidos no campo para aferição de sua acurácia. Para cada classe, foram verificados aleatoriamente 10 pontos no campo, totalizando 60 pontos. 


\subsection{Mapeamento de fitofisionomias a partir de} fotointerpretação

Um detalhamento da cobertura florestal dentro da RFMG foi obtido através de interpretação de fotografias aéreas dos anos de 1994 e 1995 (1:25.000), que correspondem às fotografias mais recentes da Reserva. As fotografias foram, primeiramente, digitalizadas em scanner, gerando imagens de resolução equivalente a 2000 dpi. A correção geométrica representou o passo seguinte, sendo feita com base em três referências cartográficas presentes nas cartas da EMPLASA (1/10.000), a saber: rede hidrográfica, corpos d'água e estradas. Todas as fotografias utilizadas para a montagem do fotomosaico da região foram georreferenciadas no programa ERDAS IMAGINE ${ }^{\mathrm{TM}} \mathrm{v} .8 .4$ utilizando-se, em média, 12 pontos de controle por fotografia. O polinômio de $2^{\circ}$ grau, que, além de considerar translação, rotação, escala e obliqüidade da imagem, também adiciona parâmetros de torção e convexidade, foi o que melhor respondeu aos testes de sobreposição das fotografias feitos durante o georreferenciamento. Por conseguinte, as fotografias assumiram geometria e projeção das cartas topográficas de referência (UTM; SAD 1969; m; 23-S). A seguir, as fotografias corrigidas correspondentes a cada ano foram sobrepostas, ainda no programa ERDAS IMAGINE ${ }^{\text {TM }}$ v. 8.4, de modo a formarem o fotomosaico correspondente à região da atual Reserva Florestal do Morro Grande.

Em uma segunda etapa, o fotomosaico gerado foi classificado visualmente utilizando-se o programa ArcView v. 8.3 e pares de fotografias aéreas observados em estereoscópio de bolso (CF-8). As classes utilizadas para a fotointerpretação foram: corpos d'água (1); vegetação natural em estádios pioneiro (2), inicial (3), médio (4) e avançado (5); áreas de vegetação natural sujeitas à influência fluvial em estádios pioneiro-inicial (6) e médio-avançado (7); reflorestamento de Pinus e Eucalyptus (8); e áreas de uso/ influência antrópica (9). A definição das classes de sucessão foi feita de acordo com as resoluções $\mathrm{n}^{\circ} 10$ e 01 do CONAMA, datadas de 19/10/1993 e 31/1/1994, respectivamente, e a resolução conjunta SMA/IBAMA/SP1 de 17/2/1994. Em uma pequena área da Reserva (0,08\%) não foi possível a observação devido à falta de registro; essa área foi então classificada como sem informação (10). Uma descrição mais detalhada das 9 classes utilizadas pode ser observada na Tabela 1.

\section{Resultados}

\section{Clima}

O Planalto Atlântico apresenta variações de clima que estão diretamente ligadas à altitude e ao tipo de relevo, que influenciam tanto a precipitação quanto a temperatura (Ponçano et al. 1981). Nesta região, observa-se climas do tipo $C f a, C f b$, $C w a$ ou $C w b$, i.e. temperado quente e úmido $(C)$, com ( $w$ ) ou sem (f) período de seca, e com temperatura do mês mais quente acima ( $a$ ) ou abaixo $(b)$ de $22^{\circ} \mathrm{C}$, segundo o sistema de classificação de Köppen (1948). As classificações variam conforme o período selecionado para a avaliação climática e a definição do período de seca (Aragaki \& Mantovani 1998).

Os dados climáticos padronizados mais completos e próximos à Reserva são os de Ibiúna, obtidos entre 19621992 (Figura 5). A partir destes dados, pode-se caracterizar o clima como Cfa (Köppen 1948), temperado quente e úmido, sem uma estação seca bem definida no inverno. A precipitação anual média é de 1339 mm, sendo que a média do mês mais seco oscila entre 30-60 mm, enquanto a do mês mais quente varia de 150 a $200 \mathrm{~mm}$. Apesar de haver uma sazonalidade na região, com uma diminuição na pluviosidade e temperaturas médias entre os meses de Abril e Agosto, não há déficit hídrico (Figura 5) e as variações de precipitação não são suficientes para caracterizar um clima com estação seca marcada - ocorre estação seca quando a precipitação média do mês menos chuvoso do inverno é dez vezes menor que a precipitação média do mês mais chuvoso do verão (Köppen 1948).

Por outro lado, dados compilados por Setzer (1946) no Morro Grande entre 1915 e 1921, e de 1927 a 1944, indicam uma precipitação média anual de 1289 mm na Cachoeira da Graça e de 1268 mm no Pedro Beicht (porém, a real precipitação deve ser maior uma vez que o intervalo entre medidas foi muito grande, possibilitando a evaporação da água coletada), também não havendo aqui estação seca pelo critério adotado por Köppen (1948). Nestes mesmos períodos, as temperaturas médias mensais na Cachoeira da Graça variaram de $12,9^{\circ} \mathrm{C}$, em Julho, a $21,1^{\circ} \mathrm{C}$, em Fevereiro (Tabela 2), caracterizando assim um clima tipo $C f b$ (Setzer 1949). As demais áreas do Morro Grande, que estão situadas em maiores altitudes, devem ter temperaturas ligeiramente mais frias, o que nos permite deduzir que o clima dominante na Reserva é o $C f b$.

A série histórica de precipitação na Cachoeira da Graça entre 1960 e 2002 apresenta uma média anual de 1357 mm, sendo Agosto o mês mais seco (38,6 mm) e Janeiro o mês mais chuvoso (213,3 mm, Tabela 2). Segundo dados da SABESP (1997), a área da bacia do rio Cotia é fortemente afetada por diversos sistemas sinóticos, ou seja, frentes frias e linhas de instabilidade. A direção predominante do vento durante todo o ano é SE/SSE, trazendo uma forte influência do Oceano Atlântico, que encontra-se a cerca de $50 \mathrm{~km}$ da Reserva. Secundariamente predominam os ventos com direção WNW/NW durante o período de maior aquecimento do dia (15 horas local). As maiores velocidades médias anuais dos ventos atingem 2,6 m/s (SABESP 1997). 


\section{Embasamento geológico}

\subsection{Regional}

Foram encontrados sete conjuntos distintos de rochas na região da Reserva Florestal do Morro Grande (Almeida et al. 1981). Devido à ausência de mapeamentos detalhados na região, esta foi a base utilizada para a compilação do mapa geológico ilustrativo (Figura 6, Tabela 3).

Hasui (1975) considera o elemento tectônico mais importante na região a existência de um conjunto de falhamentos sub-verticais (60 a 90 $)$, denominados, à luz dos conhecimentos teóricos atuais, zonas de cisalhamento dúcteis (Ramsay \& Huber 1983), ocorrendo em grande quantidade no sudeste brasileiro. As zonas de cisalhamento são grandes estruturas com centenas de quilômetros de extensão e espessuras que podem atingir centenas de metros. As principais zonas de cisalhamento da região são Taxaquara e Caucaia, sendo que a falha de Caucaia corta o Morro Grande diagonalmente na sua região norte (Figura 6, Tabela 3). Possui orientação NE-SW, acompanhando a principal foliação regional com uma largura aproximada de trezentos metros. Como decorrência da movimentação das zonas de cisalhamento, as rochas ígneas e metamórficas são parcialmente transformadas em milonitos que, na área, podem ser reconhecidos nos corpos graníticos do Morro Grande e do Morro do Tico-Tico (Simões \& Goulart 2001).

Hasui (1975) considera que o fraturamento e os planos de foliação das rochas têm um importante papel no condicionamento da drenagem, principalmente nos níveis hierárquicos mais baixos (cursos d’água de $1^{\mathrm{a}}$ e $2^{\mathrm{a}}$ ordem). Por outro lado, alguns cursos d’água são, em parte, controlados pelas intrusões graníticas.

A zona de cisalhamento Taxaquara determina a separação de dois compartimentos: o Conjunto São Roque (ao norte) e o Conjunto Paranapiacaba (ao sul), permeados por rochas sedimentares cenozóicas (Figura 6). A Reserva do Morro Grande situa-se no Conjunto Paranapiacaba. Este é constituído principalmente pelo Complexo Embu (Almeida et al. 1981, Juliani 1992) e corpos graníticos intrusivos. No Complexo Embu, predominam gnaisses e migmatitos e, em menor quantidade, ocorrem anfibolitos, mármores e quartzitos. Constituem-se, portanto, rochas de médio a alto grau de metamorfismo.

O Complexo Embu sofreu posteriormente, a intrusão de corpos graníticos como o do Morro Grande e do Morro Tico-Tico. Há uma série de evidências que define o caráter intrusivo destes corpos, sendo a mais característica a falta de passagem gradual destas rochas graníticas para as rochas encaixantes do Complexo Embu. Segundo Hasui (1975), estes corpos granitóides cobrem, aproximadamente, setenta e cinco por cento da Folha São Roque, ocorrendo principalmente ao norte da Zona de Cisalhamento de Caucaia. Com tamanho bastante variado, os granitos e granitóides cortam as demais unidades discordantemente, constituindo-se em corpos de dimensões variadas e formas irregulares. Na Folha São Roque, os maciços graníticos mais expressivos em dimensão são os de Jurupará e Caucaia, os quais são truncados pela Zona de Cisalhamento de Caucaia (Hasui 1975).

Quanto a sua colocação em relação às rochas encaixantes, estes corpos graníticos podem ser sin ou póstectônicos. Os corpos sin-tectônicos constituem a maioria, tendo sido intrudidos durante o funcionando das grandes zonas de cisalhamento, o que imprimiu nas rochas graníticas evidências de foliação, deformação e o aparecimento de faixas miloníticas de pequena espessura (menores que 1,0 $\mathrm{m})$. A deformação foi responsável pelas formas alongadas e elipsoidais destas intrusões, cujo eixo maior acompanha a direção dos principais cisalhamentos. Os corpos póstectônicos, mais recentes, foram intrudidos após o funcionamento das zonas de cisalhamento, não possuindo evidências de deformação. Estes últimos são, portanto, rochas ígneas stricto sensu, pela ausência de estruturas relacionadas ao metamorfismo.

Completando o quadro geológico regional, ocorrem as coberturas cenozóicas compostas de material inconsolidado, em particular os depósitos aluvionares ao longo das principais drenagens e os depósitos coluvionares em vertentes.

\subsection{Local}

Para a área de estudo, foram caracterizados quatro conjuntos distintos de rochas: a) rochas migmatíticas; b) rochas graníticas; c) rochas miloníticas; d) aluviões quaternários. Convém salientar que pretende-se descrever os diferentes tipos de rochas independentemente de sua posição estratigráfica, ou mesmo de eventuais interpretações feitas acerca da sua origem. O enfoque será direcionado para a descrição de suas características e peculiaridades, bem como as suas relações com os tipos de relevo e de solo presentes na área.

a) Rochas migmatíticas - Do ponto de vista litoestratigráfico, esta seqüência pertence ao Complexo Embu. Os migmatitos são rochas “mistas” que têm uma parte magmatizada. A parte preservada é o paleossoma e a parte magmatizada é designada de neossoma. Na área de estudo, o paleossoma mantém as características da rocha metamórfica original, sendo composto principalmente de feldspato, quartzo e mica (principalmente biotita). A elevada concentração de biotita fornece ao paleossoma um aspecto xistoso e coloração escura, estando, na maioria das vezes, fortemente alterado, podendo ser observado quase sempre no horizonte $\mathrm{C}$ pedológico através de minerais primários e estruturas (foliação ou xistosidade) ainda presentes. Devido ao forte intemperismo químico que estas rochas sofreram, sua cor original (cinza-claro a preta) adquire uma coloração avermelhada. Nestes horizontes C, a xistosidade quando 
perceptível, é definida principalmente por bandamento, alternando faixas ora mais quartzo-feldspáticas, ora mais micáceas. O neossoma pode ser observado em alguns perfis em associação com o paleossoma. Ao contrário destes últimos, o neossoma está mais preservado por sua constituição mineral (feldspato e quartzo) ser mais resistente ao intemperismo químico. Devido a sua composição mineralógica original, constituem-se corpos de coloração branca a cinza-claro, contrastando com as cores mais escuras do paleossoma.

b) Rochas graníticas - De uma maneira geral, estas rochas são as mais fáceis de serem mapeadas pois estão mais preservadas dos processos de intemperismo. Ocupam uma topografia mais íngreme, com morros de topos alongados, atingindo cotas até 1060 metros. Pode-se afirmar que os corpos graníticos ocupam as porções mais declivosas e elevadas da área de estudo, embora este não seja um critério absoluto. Raramente ocorrem como afloramentos “in situ”, sendo mais comum apresentarem-se como grandes matacões fora de sua posição geométrica original. Em uma primeira análise, pode-se imaginar que estes corpos graníticos não possuem estruturas metamórficas (foliações) e que tratarse-iam de corpos graníticos pós-tectônicos; porém, análises mais detalhadas constatam que a deformação afetou os corpos graníticos de maneira localizada e heterogênea. A forma alongada dos principais corpos graníticos também é uma indicação do controle estrutural destes corpos. Estas evidências são corroboradas por DAEE/UNESP (1984), que atribuem uma foliação para estes corpos. Considerando-se uma análise macroscópica, a maioria dos corpos graníticos possui uma textura equigranular (grãos com aproximadamente o mesmo tamanho) média a grosseira. Os principais minerais constituintes são o quartzo, os feldspatos (plagioclásio e microclíneo) e a biotita. A coloração, em amostra de mão, é cinza claro passando a bege, creme ou avermelhado, quando alterado.

c) Faixas miloníticas - Constitui uma unidade formada por milonitos, filonitos e ultramilonitos, que são rochas características do produto da movimentação da Zona de Cisalhamento Caucaia. Estas rochas possuem estrutura bandada, tendo seus minerais principais - quartzo e feldspato - forma bastante alongada em decorrência da intensa deformação. As faixas miloníticas são, portanto, a feição mais marcante das zonas de cisalhamento, possuindo planos de inclinação vertical (foliação) bastante contínua.

d) Aluviões quaternárias - Os depósitos aluvionares acompanham as principais drenagens existentes na área. Nestas planícies inundacionais ocorrem material inconsolidado com características locais de solos hidromórficos. Não foi possível executar sondagens verticais que estabelecesse a variação composicional destes depósitos. Dados obtidos em superfície e a partir de trado indicam sedimentos bastante argilosos e com elevada consistência e plasticidade.

\section{Relevo}

\subsection{Regional}

Segundo a divisão geomorfológica para o Estado de São Paulo realizada por Almeida (1964) e detalhada por Ponçano et al. (1981), a região da Reserva Florestal do Morro Grande está inserida no Planalto de Ibiúna, justo no limite, a oeste, com a Morraria do Embu, pertencente ao Planalto Paulistano.

O Planalto de Ibiúna é uma pequena unidade do relevo paulista, compreendida entre a Serra de Taxaquara e a zona serrana de São Roque, ao norte, e a Serra de Paranapiacaba, ao sul. Trata-se de um planalto maturamente dissecado, onde as serras mais altas atingem cerca de 1100 m de altitude, e os vales estão entre 850 e 900 m (Ponçano et al. 1981). O Planalto de Ibiúna apresenta relevo suave, de morros que mal ultrapassam uma centena de metros, entremeados por relevos mais salientes, testemunhos de superfícies mais antigas.

Segundo a classificação de Ponçano et al. (1981), a Reserva Florestal do Morro Grande apresenta predominância de relevos de degradação em planaltos dissecados, sendo grande parte sob forma de morrotes alongados e espigões (234), na região leste, ou de morros com serras restritas (245), nas bordas oeste, onde está a cabeceira do rio Sorocamirim (Figura 7, Tabela 4). No limite sul da Reserva, na divisa com a bacia do Rio Ribeira de Iguape, observa-se um trecho de relevo em escarpas festonadas (521).

\subsection{Local}

As altitudes na RFMG estão compreendidas entre 860 e 1075 m, resultando numa amplitude máxima de apenas 215 m (Figura 8). As maiores altitudes e declividades são observadas principalmente na região sul - cabeceira dos rios Cotia e Capivari - e oeste do Morro Grande - cabeceira do Sorocamirim (Figuras 8 e 10). Já as menores elevações concentram-se na porção norte da RFMG. As altitudes entre 900 e 1000 metros englobam 86,13\% da área total, sendo que apenas 4,42\% da área está em altitudes superiores a 1000 metros. A maior parte da RFMG (98,28\%) apresenta declividade abaixo de 25 graus e apenas 1,72\% estão inseridos em declividades entre 25 e 30 graus (Figura 9). As orientações de vertente na RFMG estão bem divididas entre as classes Norte, Leste, Sul, Oeste e Plano (Figura 10).

\section{Pedologia}

\subsection{Regional}

Segundo o Mapa Pedológico do Estado de São Paulo (Oliveira et al. 1999), são encontrados na Região da Reserva Florestal do Morro Grande e seu entorno os seguintes solos: latossolos vermelho-amarelos, argissolos vermelhoamarelos e cambissolos háplicos (Figura 11). 
Os latossolos representam um agrupamento de solos com horizonte B homogêneo e comparativamente espesso, apresentando boa drenagem e elevada porosidade. A evolução e a maturação destes solos podem ser caracterizadas pelo intemperismo intenso, e portanto não se percebe minerais primários com facilidade e a fração argila é constituída predominantemente por óxidos de ferro (hematita, goetita), óxidos de alumínio (gibsita) e argilominerais do grupo da caolinita. O horizonte C é geralmente espesso, refletindo as características texturais e mineralógicas da rocha original.

Os argissolos apresentam horizonte B textural, com diferenciação nítida entre os horizontes A, B e C. A argila mobiliza-se da parte mais superficial para os horizontes subsuperficiais, acumulando-se no horizonte B. Caracteriza-se por um processo incompleto de ferralitização, em conexão com paragênese caulinítica-oxídica ou virtualmente caulinítica. Dependendo da nomenclatura utilizada, estes solos são designados como Podzólico Vermelho-Amarelo, parte das Terras Roxas Estruturadas e similares, Terras Brunas, Podzólico Amarelo e/ou Podzólico Vermelho-Escuro.

Os cambissolos referem-se ao grupamento de solos não-hidromórficos com horizonte B incipiente e pouco desenvolvido, geralmente pobres em nutrientes e ácidos, e com elevados teores de alumínio. São solos de pedogênese pouco avançada, e quando provenientes de rochas cristalinas, geralmente se observa uma quantidade significativa de minerais primários fáceis de serem intemperizados. Cortes de estrada feitos em cambissolos costumam favorecer o desenvolvimento dos processos erosivos lineares, principalmente quando o horizonte $\mathrm{C}$ possui composição silto-arenosa e estruturas (foliação ou xistosidade) da rocha original. Estes solos podem ocorrer nas mais diversas formas de relevo, embora sejam mais comuns nos relevos mais íngremes e acidentados. Estes solos são predominantes no Morro Grande segundo a classificação de Oliveira et al. (1999).

\subsection{Local}

Na Região Metropolitana de São Paulo (RMSP) e adjacências, a maioria dos estudos que tratam da caracterização e evolução dos solos nos terrenos de idade pré-cambriana está mais direcionada para as questões geotécnicas (Vargas 1981, Bandini 1992, Godoy 1992). Estes trabalhos consideram a diferenciação usualmente utilizada em Geotecnia entre solos superficiais (horizontes A e B pedológicos) e os solos de alteração (horizonte $\mathrm{C}$ pedológico).

Para a análise local, procurou-se utilizar elementos de análise do solo relacionados à geotecnia e à nomenclatura pedológica de Oliveira et al. (1999). Com base na classificação pedológica, a área possui grandes extensões de cambissolos e latossolos, e uma menor presença de argissolos na sua porção norte. Estes solos serão descritos a seguir.
Os latossolos na área possuem coloração vermelhoamarelada com uma textura predominante argilosa ou muito argilosa. Embora os latossolos tendam a ocorrer em relevos mais suaves, que favorecem a lixiviação de sílica e a manutenção de ferro e alumínio, podem ocorrer também em terrenos mais íngremes. Isto ocorre na área estudada, onde os latossolos estão presentes tanto em regiões declivosas, quanto em regiões mais suaves, como os topos de morros. De uma maneira geral, são solos profundos e com elevado grau de intemperismo, com horizonte B normalmente excedendo 1,50 m de espessura. Em amostras classificadas como latossolos foram realizadas análises granulométricas no Laboratório de Mecânica dos Solos, da UNESP, Campus de Guaratinguetá, cujos resultados mostram que a composição de argila variou entre 38 e $63 \%$ para o horizonte B. As elevadas quantidades relativas de argilas encontrada nos latossolos da região fazem com que sejam pouco suscetíveis aos processos erosivos acelerados.

Os argissolos encontrados na área são do tipo vermelho-amarela. De uma maneira geral, são solos relativamente profundos, onde se observa o enriquecimento em argila no horizonte $\mathrm{B}$. O horizonte A possui pequena espessura variando de 15 a $30 \mathrm{~cm}$. Apresenta uma variação de cinza a castanho na coloração e seus constituintes minerais tendem a se agrupar formando torrões, devido ao papel cimentante dos minerais argilosos e da matéria orgânica. A maior parte das raízes das plantas tende a se concentrar neste horizonte, embora elas possam se estender para o horizonte inferior. O horizonte B varia de 0,60 a 2,0 m de profundidade, sendo possível normalmente estabelecer uma diferenciação marcante entre os horizontes $B_{1}$ e $B_{2}$, tratando-se, portanto, de solos B-texturados. Raramente caracteriza-se um horizonte $B_{3}$, na transição com o horizonte C. A cor predominante do horizonte B nos perfis da região é amarelo-avermelhado, com uma gradação para tonalidades mais avermelhadas com o aumento da profundidade. No caso das áreas onde ocorrem migmatitos, os solos são predominantemente silto e argilo-arenosos devido à alteração, completa ou parcial, do feldspato e ferromagnesianos (biotita), e à preservação dos minerais de quartzo. Apresentam alternância de níveis esbranquiçados a amarelo-avermelhado. Os corpos graníticos tendem a produzir solos mais arenosos, com permeabilidade mais elevada do que as porções xistosas dos migmatitos.

Os cambissolos se concentram nas regiões de relevos mais íngremes e no terço superior das encostas, podendo localmente estar associados a solos litólicos (sem horizonte B), onde está presente uma maior quantidade de afloramentos rochosos. A presença de blocos e matacões é muito constante na maioria dos perfis analisados. Os cambissolos também podem ocorrer em terrenos aplainados das planícies aluvionares, onde o lençol freático encontrase relativamente elevado. Desta forma, estão relacionados tanto aos depósitos coluvionares (em vertente) quanto aos 
depósitos aluvionares das regiões alveolares. Em ambos os casos, o horizonte B incipiente raramente ultrapassa $50 \mathrm{~cm}$ de espessura. No caso dos cambissolos relacionados aos depósitos coluvionares, sua coloração é normalmente amarelo-avermelhado, apresentando algumas pontuações esbranquiçadas provenientes da decomposição do feldspato. De uma maneira geral, possuem uma menor proporção de argila que os latossolos, embora mostrem um comportamento ligeiramente plástico. Não foram observados processos erosivos significativos relacionados a este solo, o que pode sugerir que a quantidade da fração argilosa presente no solo foi suficiente para evitar a aceleração deste processo. Os cambissolos relacionados às aluviões possuem coloração cinza-escuro e são mais argilosos que aqueles encontrados nos depósitos coluvionares. Naturalmente, possuem limitações maiores à drenagem interna, pois o lençol freático está muito próximo da superfície.

\section{Uso e cobertura do território}

\subsection{Mapeamento da vegetação do entorno da RFMG}

A ocupação e o uso das terras no entorno da RFMG apresenta um padrão altamente fragmentado (Figura 12). A expansão das atividades agrícolas e da urbanização provocou alterações profundas em sua cobertura vegetal original. Além da redução da cobertura florestal, a maioria dos remanescentes é de dimensão reduzida e teve sua composição e estrutura muito modificada pelo homem. A floresta original foi substituída por extensas áreas antrópicas onde, atualmente, encontram-se fragmentos florestais de diferentes dimensões, formas e graus de conservação e isolamento. A Reserva Florestal do Morro Grande é uma das poucas áreas a apresentar florestas em estádios mais avançados de sucessão. A Tabela 5 apresenta as classes de cobertura do solo e as porcentagens em que estas são encontradas na área considerada por este relatório. A acurácia total do mapa foi de 83,33\%, devido à confusão entre as áreas de campo e de agricultura.

Considerando o Morro Grande e o conjunto florestal presente na Serra de Paranapiacaba (Figura 12), a região apresenta um predomínio de florestas em estádios médios a avançados de sucessão (praticamente 60\%). Apenas 3,3\% da região foi classificada em estádios iniciais de sucessão, porém é possível que parte deste estádio tenha sido confundido e incluído na classe de sucessão média a avançada. A verificação de campo não permitiu detectar esse erro, porém análises com fotografias aéreas para áreas adjacentes ao Morro Grande permitem inferir uma cobertura mais extensa de vegetação em estádio inicial de sucessão. Também houve confusão da classe de sucessão inicial com as áreas de reflorestamento por Pinus spp e Eucalyptus spp, não permitindo separar estas duas classes em tratamentos automáticos.
A área agrícola apresenta uma rápida dinâmica, que está na origem da confusão entre agricultura e campos. A agricultura é praticada em pequenas parcelas que são alternadamente utilizadas, ao longo dos anos, para cultivo e descanso da terra, sendo classificadas então como áreas agrícolas ou de campo. Na realidade, há poucas áreas utilizadas exclusivamente para pastagem, sendo a maior parte das áreas classificadas como “campo” terras de uso agrícola em descanso (pousio). Por conseqüência, cerca de 25\% da região é utilizado par fins agrícolas (Tabela 5).

Finalmente, a cobertura de $12,5 \%$ de áreas urbanas corresponde à mancha urbana da Grande São Paulo, incluindo, em particular, os aglomerados de Cotia, Embu, Itapecerica da Serra, Taboão da Serra, Osasco, e Vargem Grande Paulista, além da zona oeste da cidade de São Paulo, cujo centro está a apenas 35 km da Reserva.

\subsection{Mapeamento de fitofisionomias da RFMG}

Dos 10.870,08 ha mapeados, cerca de 87\% (9.400,62 ha) permanecem cobertos por Floresta Ombrófila Densa Montana, em sua maioria em estádios sucessionais médio/ avançado (6949,8 ha ou 63,93\%) e avançado/maduro (2450,91 ha ou 22,55\%) de regeneração (Tabela 6). Áreas correspondentes a estádios iniciais de regeneração (pioneiro e inicial/médio) ocupam apenas uma pequena parcela da RFMG, correspondendo a 373,52 ha (3,44\%). Em relação ao grau de fragmentação, detectado em um primeiro momento pelo número de polígonos gerados na fotointerpretação, tem-se que as matas em estádio médio/ avançado de regeneração 49 polígonos apresentam-se menos fragmentadas (49 polígonos com tamanho médio de 141,83 ha) em relação às matas em estádio avançado/ maduro de regeneração (242 polígonos, com tamanho médio de 10,13 ha).

A área das represas de Cachoeira da Graça e Pedro Beicht, somadas a outros pequenos corpos d'água, totalizaram 354,4 ha (3,26\%). A vegetação natural ripária representa 564,92 ha $(5,2 \%)$, sendo que a maior parte dessa vegetação $(470,74$ ha ou 4,33\%) encontra-se em estádios mais avançados de regeneração. As áreas sujeitas a ações de manejo, como reflorestamento e outros usos, totalizaram 168,55 ha (1,48\%), o que indica a existência de influência antrópica na regeneração das áreas naturais do Morro Grande (Figura 13).

\section{Os levantamentos biológicos}

A caracterização florística e faunísta do Morro Grande será feita numa série de artigos enfatizando a comunidade arbórea (Catharino et al. 2006), as plântulas (Alves \& Metzger 2006), grande mamíferos (Negrão \& Valladares-Pádua 2006), pequenos mamíferos (Pardini \& Umetsu 2006), aves (Develey \& Martensen 2006), répteis e anfíbios (Dixo \& Verdade 2006), e aranhas orbitelas (Nogueira et al. 2006). 
Estes levantamentos foram feitos em treze diferentes locais dentro do Morro Grande (Tabela 7). Seis destes sítios foram usados mais frequentemente, sendo que três estão situados em áreas florestais em estádios intermediários/avançados de sucessão (A, B e C), enquanto que os outros três estão em áreas de floresta mais madura (Quilombo, Grilos e Torres). A maior parte destes sítios está situada em embasamentos graníticos e apresenta predominantemente cambissolos háplicos (Tabela 7). O relevo varia, sendo em geral mais suave (morros) em altitudes mais baixas, e mais acidentado nas áreas mais altas (> 1000 m), em particular em “Torres”, que já está no limite da escarpa da Serra de Paranapiacaba.

Buscando uma certa integração na apresentação dos artigos de caracterização biológica, procurou-se padronizar a estrutura e os principais enfoques na análise dos dados. Todos os artigos apresentam: i) uma listagem comentada das espécies; ii) uma descrição dos parâmetros fundamentais das comunidades, em termos de composição e riqueza, e sobre sua variação espacial; iii) comparações, quando pertinentes, com levantamentos feitos em áreas adjacentes ou ambientes similares, ponderando as interpretações em função de particularidades ou diferenças nas metodologias de levantamento empregadas; iv) implicações em termos de conservação. Os artigos serão assim um misto de apresentação de inventários, com análises ecológicas no nível de comunidade, e implicações para conservação. Estes artigos farão sempre referência ao presente manuscrito quando necessitarem citar algum dado sobre a estrutura física do meio, ou mesmo para localizarem as áreas de estudo. Será seguida a codificação das áreas de estudo conforme a Figura 13. Além dos artigos centrados nas diferentes comunidades vegetais e animais, haverá um artigo final procurando integrar o conjunto de dados obtidos, ressaltando a relevância e implicações dos padrões observados (Metzger et al. 2006).

\section{Agradecimentos}

O trabalho na Reserva do Morro Grande só foi possível graças à grande receptividade do Sr. José Roberto Nali, responsável pela Reserva Florestal do Morro Grande, e ao apoio da FAPESP, que financiou o projeto "Conservação da Biodiversidade em Paisagens Fragmentadas no Planalto Atlântico de São Paulo" (processo 99/05123-4) dentro do programa BIOTA. Este trabalho contou também com o apoio da SABESP, que ao financiar a redação de um pré-plano de manejo para a RFMG, nos permitiu compilar os dados obtidos no Morro Grande e organizar um banco de dados. Este manuscrito contou ainda com o trabalho de diversos alunos, muitos dos quais participaram das atividades do pré-plano de manejo. Agradecemos o Dr. Carlos Joly, editor-chefe da BIOTA NEOTROPICA, por ter apoiado a idéia da publicação desta série de artigos sobre a Reserva do
Morro Grande, e o Dr. Thomas Lewinsohn, por ter aceito o árduo trabalho de ser o editor associado a estes artigos. O presente manuscrito contou ainda com valiosos comentários feitos pelo Dr. Cláudio Bohrer e por um assessor anônimo, aos quais agradecemos.

\section{Referências}

AGUILAR, J.B.V. 1998. A comunidade de abelhas (Hymenoptera: Apoidea) da Reserva Florestal de Morro Grande, Cotia, São Paulo. Tese de doutorado, Instituto de Biociências, Universidade de São Paulo, São Paulo.

ALMEIDA, F.F.M. 1964. Fundamentos geológicos do relevo paulista. In Instituto Geográfico e Geológico, São Paulo, IGG p.169-262.

ALMEIDA, F.F.M., HASUI, Y., PONÇANO, W.L., DANTAS, A.S.L., CARNEIRO, C.D.R., MELO, M.S. \& BISTRICH, C.A. 1981. Mapa Geológico do Estado de São Paulo. Escala 1:500.000. Texto Explicativo. São Paulo, IPT (Vol. 1).

ALVES, L.F. \& METZGER, J.P. 2006. A regeneração florestal em áreas de floresta secundária na Reserva Florestal do Morro Grande, Cotia, SP. Biota Neotrop. 6(2): http:// www.biotaneotropica.org.br/v6n $2 / \mathrm{pt} /$ abstract?article+bn00606022006 (último acesso em 03/ 05/2006).

ARAGAKI, S. \& MANTOVANI, W. 1998. Caracterização do clima e da vegetação de remanescente florestal no planalto paulistano (SP). In Anais do IV Simpósio de Ecossistemas Brasileiros. Pub. Aciesp 104: 25-36.

BANDINI, M.P. 1992. Considerações sobre o ordenamento do uso do solo urbano em áreas de risco geológico: o caso do Parque Lanel - Franco da Rocha, SP. Dissertação de mestrado, IGCE, Universidade Estadual Paulista, Rio Claro.

BREGA, D. 1995. Sistema Cotia: análise preliminar de perigos e riscos - Sistema Cotia - RMSP. Relatório Técnico, SABESP, São Paulo.

BREGA FILHO, D. \& BOMBONATO JR., C. 1992. Plano de Proteção e Recuperação da Reserva Florestal do Morro Grande. Reservatório Pedro Beicht e Cachoeira das Graças. Relatório Técnico. Sistema Alto Cotia, Região Metropolitana de São Paulo.

BROWN, S. \& LUGO, A.E. 1990. Tropical secondary forests. J. Trop. Ecol. 6:1-32.

CARNEIRO, C.D. 1983. Análise estrutural do Grupo Roque na faixa entre o pico do Jaraguá e a Serra dos Cristais. Tese de doutorado, Instituto de Geociências, Universidade de São Paulo, São Paulo.

CATHARINO, E.L.M., METZGER, J.P. \& ALVES, L.F. (Coordenadores). 2004. Plano de Gestão Emergencial da Reserva Florestal do Morro Grande. Relatório Técnico. Stemag Engenharia, Laboratório de Ecologia da Paisagem e Conservação, Depto. de Ecologia, USP \& SELVA Sociedade Ecológica Verde-Amarelo. São Paulo. 
CATHARINO, E.L., BERNACCI, L.C., FRANCO, G.A.D.C., DURIGAN, G. \& METZGER, J.P. 2006. Aspectos da composição e diversidade do componente arbóreo das florestas da Reserva Florestal do Morro Grande, Cotia, SP. Biota Neotrop. 6(2): http://www.biotaneotropica.org.br/v6n2/pt/ abstract?article+bn00306022006 (último acesso em 03/05/2006).

CROSTA, A.P. 1992. Processamento digital de imagens de sensoriamento remoto. Editora da UNICAMP, Campinas.

DEPARTAMENTO DE ÁGUA E ENERGIA ELÉTRICA/ Universidade Estadual Paulista (DAEE/UNESP). 1984. Mapa Geológico do Estado de São Paulo. Escala 1:250.000. Governo do Estado de São Paulo, Secretaria de Obras e do Meio Ambiente. São Paulo.

DEAN, W. 1995. A ferro e fogo - A história e a devastação da Mata Atlântica brasileira. Companhia das Letras, São Paulo.

DEVELEY, P.F. \& MARTENSEN, A.C. 2006. As aves da Reserva Florestal do Morro Grande, Cotia (SP). Biota Neotrop. 6(2): http://www.biotaneotropica.org.br/ v6n2/pt/abstract?article+bn00906022006 (último acesso em 03/05/2006).

DIXO, M. \& VERDADE, V.K. 2006. Herpetofauna de serrapilheira da Reserva Florestal do Morro Grande, Cotia (SP). Biota Neotrop. 6(2): http:// www.biotaneotropica.org.br/v6n $2 / \mathrm{pt} /$ abstract?article+bn00706022006 (último acesso em 03/05/2006).

EMBRAPA. 1999. Sistema brasileiro de classificação de solos. Centro Nacional de Pesquisa de Solos (Rio de Janeiro, RJ). Embrapa Produção de Informação, Brasília.

GODOY, H. 1992. Características geológicas e geotécnicas dos produtos de alteração de granitos e gnaisses nos arredores de São Paulo. Dissertação de mestrado, Instituto de Geociências, Universidade de São Paulo, São Paulo.

GOULART, W. 2004. Relações entre relevo e vegetação arbórea em fragmentos florestais de Mata Atlântica no Planalto de Ibiúna, SP. Dissertação de mestrado. Instituto de Biociências, Universidade de São Paulo, São Paulo.

HASUI, Y. 1975. Geologia da Folha de São Roque, São Paulo. Boletim IG-USP 6:95-108.

JULIANI, C. 1992. O embasamento pré-cambriano da Bacia de São Paulo. In Seminário Problemas Geológicos e Geotécnicos na região Metropolitana de São Paulo. São Paulo, ABAS/ABGE/SBG-SP. p. 3-20.

KÖPPEN, W. 1948. Climatologia. Fondo de Cultural Econômica, México.
METZGER, J.P., ALVES, L.F., PARDINI, R., DIXO, M., NOGUEIRA, A.A., NEGRÃO, M.F.F., MARTENSEN, A.C. \& CATHARINO, E.L.M. 2006. Características ecológicas e implicações para a conservação da Reserva Florestal do Morro Grande. Biota Neotrop. 6(2): http://www.biotaneotropica.org.br/v6n2/pt/ abstract?article+bn00506022006 (último acesso em 03/05/2006).

MINISTÉRIO DO MEIO AMBIENTE (MMA). 2000. Avaliações e ações prioritárias para a conservação da biodiversidade da Mata Atlântica e campos sulinos. Conservation International do Brasil, Fundação SOS Mata Atlântica, Fundação Biodiversitas, Instituto de Pesquisas Ecológicas, Secretaria do Meio Ambiente do Estado de São Paulo, SEMAD/Instituto Estadual de Florestas-MG. MMA/ SBF, Brasília.

MORELLATO, L.P.C. 1992. História natural da Serra do Japi: ecologia e preservação de uma área florestal no sudeste do Brasil. Editora UNICAMP/FAPESP, Campinas.

NEGRÃO, M.F.F. \& VALLADARES-PÁDUA, C. 2006. Registros de mamíferos de maior porte na Reserva Florestal do Morro Grande, São Paulo. Biota Neotrop. 6(2): http://www.biotaneotropica.org.br/v6n2/pt/ abstract?article+bn00806022006 (último acesso em 03/05/2006).

NOGUEIRA, A.A., PINTO DA ROCHA, R. \& BRESCOVIT, A.D. 2006. Comunidade de aranhas orbitelas (Arachnida - Araneae) da região da Reserva Florestal do Morro Grande, Cotia, São Paulo, Brasil. Biota Neotrop. 6(2): $\underline{\text { http:// }}$ www.biotaneotropica.org.br/v6n $2 / \mathrm{pt} /$ abstract?article+bn00206022006 (último acesso em 03/05/2006).

OLIVEIRA, J.B., CAMARGO, M.N., ROSSI, M. \& CALDERANO FILHO, B. 1999. Mapa Pedológico do Estado de São Paulo. 1: 500.000. Instituto Agronômico, Campinas.

PARDINI, R. \& UMETSU, F. 2006. Pequenos mamíferos não-voadores da Reserva Florestal do Morro Grande - distribuição das espécies e da diversidade em uma área de Mata Atlântica. Biota Neotrop. 6(2): http:// www.biotaneotropica.org.br/v6n2/pt/ abstract?article+bn01006022006 (último acesso em 03/05/2006).

PONÇANO, W.L., CARNEIRO, C.D.R., BISTRICHI, C.A., ALMEIDA, F.F.M. \& PRANDINI, F.L. 1981. Мара Geomorfológico do Estado de São Paulo. Escala: 1:1.000.000. São Paulo, IPT (IPT, Monografias, 5).

PORTELA, R.C.Q. \& SANTOS, F.A.M. 2003. Alometria de plântulas e jovens de espécies arbóreas: copa $\mathrm{x}$ altura. Biota Neotrop. 3(2): http://www.biotaneotropica.org.br/ v3n2/pt/abstract?article+BN00503022003 (último acesso em 02/05/2006). 
RAMSAY, J, \& HUBER, M.I. 1983. The techniques of modern structural geology. Vol. 1 Strain Analysis. Academic Press, Londres.

ROSS, J.L.S. \& MOROZ, I.C. 1997. Mapa Geomorfológico do Estado de São Paulo: escala 1:500.000. FFLCH-USP, IPT \& Fapesp, São Paulo.

SABESP. 1997. Reabilitação Ambiental do Sistema Produtor Baixo Cotia (coord.: Brega Filho., D, Salati, E. \& Santos, R. F.). Programa de Conservação do Sistema Cotia. Relatório Técnico e mapas temáticos. Volumes I e II. Sabesp, São Paulo.

SEABRA, M. 1971. Vargem Grande: organização e transformações de um setor do cinturão verde paulistano. Instituto de Geografia, USP, São Paulo.

SETZER, J. 1946. A distribuição normal das chuvas no estado de São Paulo. Bragantia 15:193-249.

SETZER, J. 1949. Os solos do estado de São Paulo. Conselho Nacional de Geografia, Publicação 6, Série “Livros”, Rio de Janeiro.

SIMÕES, S.J.C. \& GOULART, W. 2001. Geologia, relevo e formações superficiais na região das Serranias de São Roque e do Planalto de Ibiúna. Anexo 1. In Conservação da Biodiversidade em Paisagens Fragmentadas no Planalto Atlântico de São Paulo - Relatório I FAPESP, Processo No 99/05123-4 (J.P. Metzger, coord). Universidade de São Paulo, São Paulo.

TEIXEIRA, A.M.G. 2005, Modelagem da dinâmica de uma paisagem do Planalto de Ibiúna, SP, com inferências sobre a sua estrutura futura. Dissertação de mestrado, Instituto de Biociências, Universidade de São Paulo, São Paulo.

TUNDISI, J.G. 1991. Reservatório Pedro Beicht - Limnologia e perspectivas para o Gerenciamento - Relatório científico apresentado à SABESP.

UEHARA-PRADO, M., A.V.L. FREITAS, K.S. BROWN JR. \& FRANCINI, R.B. 2004. Guia ilustrado das borboletas frugívoras da Reserva do Morro Grande e adjacências. Biota Neotrop. 4: 1: http://www.biotaneotropica.org.br/ v4n1/pt/abstract?inventory+BN00504012004 (último acesso em 02/05/2006).

VARGAS, M. 1981. Progresso dos estudos sobre solos tropicais em São Paulo. In Anais Simpósio Brasileiro sobre Solos Tropicais em Engenharia. V. 2.

VELOSO, P.H., RANGEL-FILHO, A.L.R. \& LIMA, J.C.A. 1991. Classificação da vegetação brasileira adaptada a um sistema universal. IBGE, Rio de Janeiro.

VICTOR, M.A.M., FERNÁNDEZ,A.D., FERNÁNDEZ, L.V., MONTRIGAUD, M.E.B. D’A., AMAZONAS, M.C. \& SERRANO, O. 1998. A Reserva da Biosfera do Cinturão Verde da Cidade de São Paulo. Workshop: Plano de Gestão para a Reserva da Biosfera do Cinturão Verde da Cidade de São Paulo. Instituto Florestal, São Paulo.
Título: Uma área de relevante interesse biológico, porém pouco conhecida: a Reserva Florestal do Morro Grande.

Autores: Metzger, J.P.; Alves. L.F.; Goulart, W.; Teixeira, A.M.G.; Simões, S.J.C., Catharino, E.L.

Biota Neotropica, Vol. 6 ( número 2): 2006

http://www.biotaneotropica.org.br/v6n2/pt/ abstract?article+bn00206022006

Recebido em 17/11/2004 - Versão reformulada recebida em 25/08/2005 - Publicado em 01/05/2006

ISSN 1676-0603 
Tabela 1. Descrição das nove classes utilizadas para a fotointerpretação da área referente à Reserva Florestal do Morro Grande (1994/1995) Table 1. Main characteristics and aerial photograph patterns of the nine classes used for land cover and land use mapping of the Morro Grande Forest Reserve. .

\begin{tabular}{|c|c|c|}
\hline Classe & Descrição & Padrão na fotografia \\
\hline (1) Corpos d'água & $\begin{array}{l}\text { Áreas referentes a represas, lagoas, lagos e } \\
\text { afins }\end{array}$ & $\begin{array}{l}\text { Granulosidade fotográfica homogênea } \\
\text { característica de corpos d'água }\end{array}$ \\
\hline $\begin{array}{l}\text { (2) Vegetação natural } \\
\text { - estádio pioneiro }\end{array}$ & Áreas com vegetação herbáceo-arbustiva & Granulosidade fotográfica muito fina \\
\hline $\begin{array}{l}\text { (3) Vegetação natural } \\
\text { - estádio inicial }\end{array}$ & $\begin{array}{l}\text { Áreas com vegetação arbustiva, arbustivo- } \\
\text { arbórea e/ou arbórea baixa }\end{array}$ & Granulosidade fotográfica fina \\
\hline $\begin{array}{l}\text { (4) Vegetação natural } \\
\text { - estádio médio }\end{array}$ & $\begin{array}{l}\text { Áreas com vegetação arbórea, emergentes } \\
\text { raras }\end{array}$ & Granulosidade fotográfica média a grossa \\
\hline $\begin{array}{l}\text { (5) Vegetação natural } \\
\text { - estádio avançado }\end{array}$ & $\begin{array}{l}\text { Áreas com vegetação arbórea densa, } \\
\text { emergentes comuns }\end{array}$ & Granulosidade fotográfica grossa \\
\hline $\begin{array}{l}\text { (6) Áreas de } \\
\text { vegetação natural } \\
\text { sujeitas à influência } \\
\text { fluvial em estádio } \\
\text { pioneiro-inicial }\end{array}$ & $\begin{array}{l}\text { Áreas com vegetação natural herbáceo- } \\
\text { arbustiva, arbustiva, arbustivo-arbórea e/ou } \\
\text { arbórea baixa }\end{array}$ & $\begin{array}{l}\text { Granulosidade fotográfica muito fina a } \\
\text { fina, no entorno da rede hidrográfica, com } \\
\text { padrão diferente da vegetação não-sujeita à } \\
\text { influência fluvial }\end{array}$ \\
\hline $\begin{array}{l}\text { (7) Áreas de } \\
\text { vegetação natural } \\
\text { sujeitas à influência } \\
\text { fluvial em estádio } \\
\text { médio-avançado }\end{array}$ & $\begin{array}{l}\text { Áreas com vegetação natural arbórea e/ou } \\
\text { arbórea densa }\end{array}$ & $\begin{array}{l}\text { Granulosidade fotográfica média a grossa, } \\
\text { no entorno da rede hidrográfica, com } \\
\text { padrão diferente da vegetação não-sujeita à } \\
\text { influência fluvial }\end{array}$ \\
\hline (8) Reflorestamento & $\begin{array}{l}\text { Áreas com vegetação de padrão bastante } \\
\text { homogêneo }\end{array}$ & $\begin{array}{l}\text { Granulosidade fotográfica homogênea } \\
\text { característica de área de reflorestamento }\end{array}$ \\
\hline $\begin{array}{l}\text { (9) Uso/influência } \\
\text { antrópica }\end{array}$ & $\begin{array}{l}\text { Áreas sujeitas a queimadas constantes, } \\
\text { retirada de vegetação e manejo diverso }\end{array}$ & $\begin{array}{l}\text { Granulosidade fotográfica bastante } \\
\text { heterogênea }\end{array}$ \\
\hline
\end{tabular}


Tabela 2. Médias mensais de temperatura (Setzer 1949) e de precipitação (Sistema Alto Cotia, SABESP) obtidos na Cachoeira da

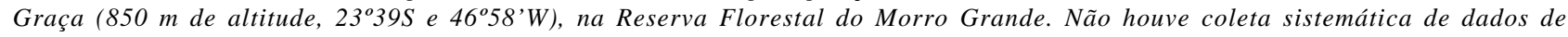
temperatura após 1941 na RFMG.

Table 2. Month average temperature (Setzer 1949) and precipitation (Alto Cotia water production system) obtained in the "Cachoeira da Graça” reservoir (23 395 and 46 58'W; altitude: 850 m), Morro Grande Forest Reserve. After 1941, data collection of temperature was not a regular.

Temperatura $\left({ }^{\circ} \mathrm{C}\right)$ 1916 a $1921 \quad 1927$ a 1932,1935 a 1936, 1939 a 1941

\begin{tabular}{lllr}
\hline Janeiro & 19,8 & 20,7 & 213,28 \\
Fevereiro & 19,6 & 21,1 & 201,57 \\
Março & 19,0 & 20,5 & 144,40 \\
Abril & 17,5 & 19,2 & 72,54 \\
Maio & 15,3 & 16,8 & 72,21 \\
Junho & 13,5 & 15,8 & 61,07 \\
Julho & 12,9 & 15,2 & 48,30 \\
Agosto & 13,8 & 15,7 & 38,60 \\
Setembro & 15,6 & 16,4 & 83,75 \\
Outubro & 16,5 & 17,7 & 122,21 \\
Novembro & 17,8 & 18,6 & 134,14 \\
Dezembro & 18,7 & 20,4 & 165,13 \\
& & & \\
MÉDIA & 16,7 & 18,2 & 1357,19 \\
\hline
\end{tabular}

Precipitação (mm)

1960 a 2002 
Tabela 3. Rochas da região da Reserva Florestal do Morro Grande de acordo com o levantamento de Almeida et al. (1981), na escala 1/ 1.000.000 (mapa na Figura 6).

Table 3. Rocks from Morro Grande Forest Reserve region according to the map from Almeida et al. (1981) (scale: 1/1.000.000; see map in Figure 6).

Eon Fanerozóico/Era Cenozóica/Período Quaternário/Época Holoceno $(1,8$ m. a. $\rightarrow)$

Sedimentos aluvionares Qa - Aluviões em geral, incluindo areias inconsolidadas de granulação variável, argilas e cascalheiras fluviais subordinadamente, em depósitos de calha e/ou terraços.

Eon Criptozóico/Era Proterozóica/Período Proterozóico Superior (1.000 m. a. - 570 m. a.)

Grupo Açungui - Complexo Pilar

PSpX - quartzo-mica xistos, biotita-quartzo xistos, muscovita-quartzo xistos, granada-biotita xistos, xistos grafitosos, clorita xistos, sericita-biotita, talco xistos, magnetita xistos e calcoxistos com intercalações subordinadas de filitos, quartzitos, mármores, calcossilicáticas e metassiltitos.

\section{Grupo Açungui - Complexo Embu}

PseM - Migmatitos heterogêneos de estruturas variadas, predominando estromatitos de paleossoma xistoso, gnáissico ou anfibolítico; migmatitos homogênios variados predominando os de natureza homofânica, oftalmítica e facoidal;

PseB - com ocorrência subordinada de corpos metabásicos

\section{Grupo São Roque}

PSsC - calcários dolomíticos, calcíticos e hornfels calcossilicáticos em aurélas termo-metamórficas;

PSsF - filitos, quartzo filitos e filitos grafitosos em sucessões rítmicas, incluindo subordinadamente metassiltitos e quartzo xistos, micaxistos e quartzitos.

\section{Suites Graniticas Sintectônicas}

Fácies Cantareira (PSyc) - Corpos para-autóctones e alóctones, foliados, granulação fina a média, textura porfirítica frequente; contatos parcialmente concordantes e composição granodiorítica a granítica. 
Tabela 4. Formas de relevo presentes na região da Reserva Florestal do Morro Grande segundo sistema de classificação proposto por Ponçano et al. (1981) (Figura 7).

Table 4. Main relief units observed in the Morro Grande Forest Reserve region according to the classification system proposed by Ponçano et al. (1981) (Figure 7).

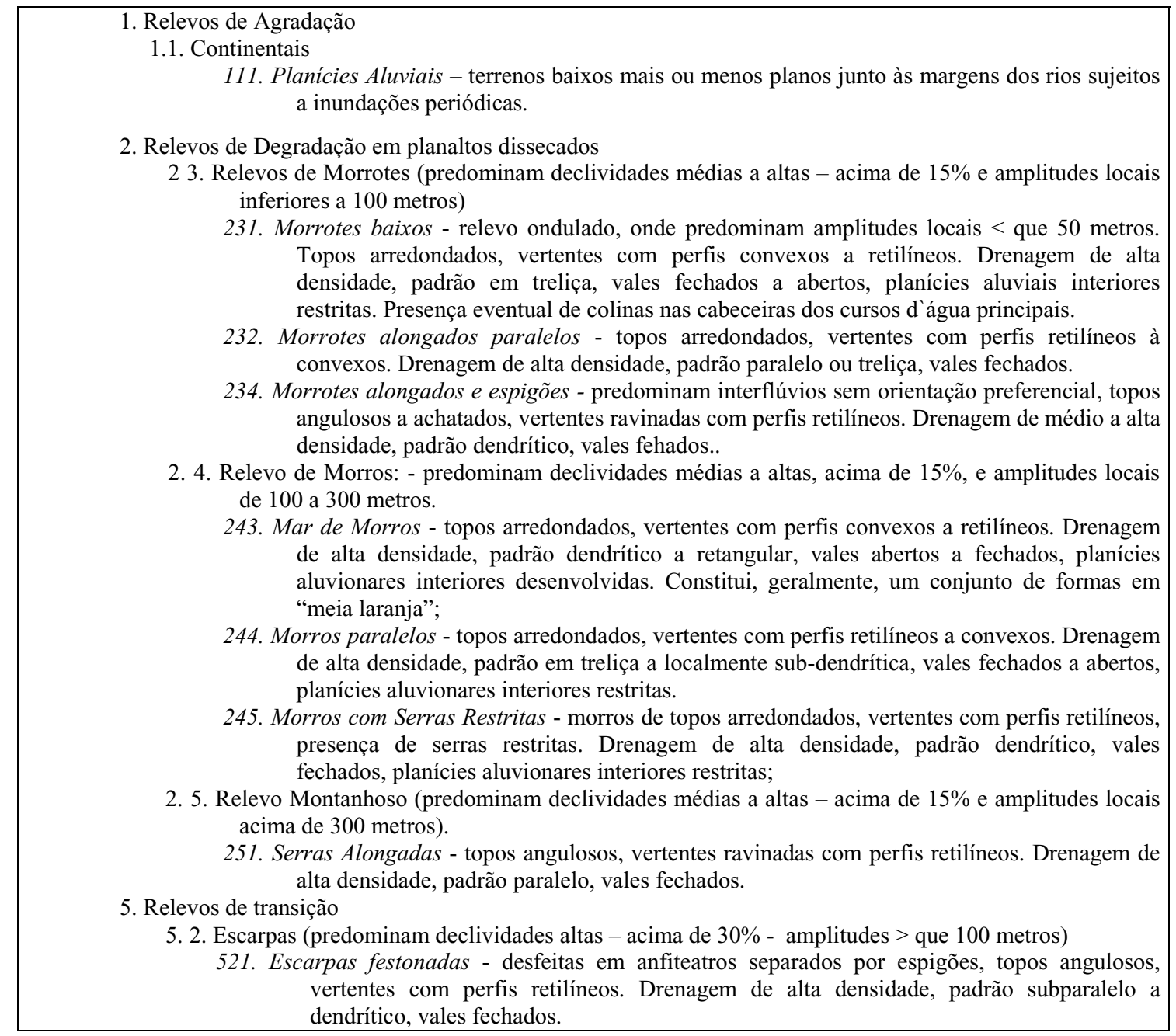


Tabela 5. Porcentagem de ocupação de cada classe de cobertura em relação à área total da RFMG e do entorno considerado (mapa na Figura 12). Calculado a partir da imagem LANDSAT-7 ETM+ classificada.

Table 5. Cover percentage of each land use and land cover class considering the area inside and around the Morro Grande Forest Reserve (map in Figure 12). Obtained from a classified LANDSAT-7 ETM+ image.

\section{Classe de cobertura}

Área urbana

Água

Agricultura

Campo ou área degradada

Vegetação em estádios sucessionais iniciais e reflorestamentos

Vegetação em estádios sucessionais médios a avançados

\section{Cobertura (\%)}

12,5

1,3

16,3

9,1

3,3

57,5

http://www.biotaneotropica.org.br 
Tabela 6. Número de polígonos, área total e porcentagem de ocupação (em relação à área total da RFMG) de cada uma das 10 classes obtidas pela fotointerpretação (1994/1995) (mapa na Figura 13).

Table 6. Number of polygons, total area and cover percentage (in relation to the Morro Grande Forest Reserve area) for the 10 land use and land cover classes obtained by photo interpretation (1994/1995) (map in Figure 13).

\begin{tabular}{|c|c|c|c|}
\hline Classe & Número de polígonos & Área total (ha) & Porcentagem \\
\hline (1) Corpos d'água & 4 & 354,40 & 3,26 \\
\hline $\begin{array}{l}\text { (2) Vegetação natural - estádio } \\
\text { pioneiro }\end{array}$ & 44 & 228,32 & 2,10 \\
\hline $\begin{array}{l}\text { (3) Vegetação natural - estádio } \\
\text { inicial/médio }\end{array}$ & 62 & 145,20 & 1,34 \\
\hline $\begin{array}{l}\text { (4) Vegetação natural - estádio } \\
\text { médio/avançado }\end{array}$ & 49 & 6949,70 & 63,93 \\
\hline $\begin{array}{l}\text { (5) Vegetação natural - estádio } \\
\text { avançado/maduro }\end{array}$ & 242 & 2450,91 & 22,55 \\
\hline $\begin{array}{l}\text { (6) Áreas de vegetação natural } \\
\text { sujeitas à influência fluvial em } \\
\text { estádio pioneiro-inicial }\end{array}$ & 33 & 94,18 & 0,87 \\
\hline $\begin{array}{l}\text { (7) Áreas de vegetação natural } \\
\text { sujeitas à influência fluvial em } \\
\text { estádio médio-avançado }\end{array}$ & 53 & 470,74 & 4,33 \\
\hline (8) Reflorestamento & 4 & 83,86 & 0,77 \\
\hline (9) Uso/Influência antrópica & 6 & 84,70 & 0,78 \\
\hline (10) Sem informação & 1 & 8,79 & 0,08 \\
\hline TOTAL & 498 & 10870,08 & 100,00 \\
\hline
\end{tabular}


Tabela 7. Tipo de vegetação e principais características abióticas dos sítios de levantamento biológico na Reserva Florestal do Morro Grande (ver distribuição espacial na Figura 13 - sítios ordenados por estádio de sucessão).

Table 7. Vegetation and main abiotic characteristics of the biological sampling sites in the Morro Grande Forest Reserve (see their spatial distribution in Figure 13; sites are ordered by successional stage).

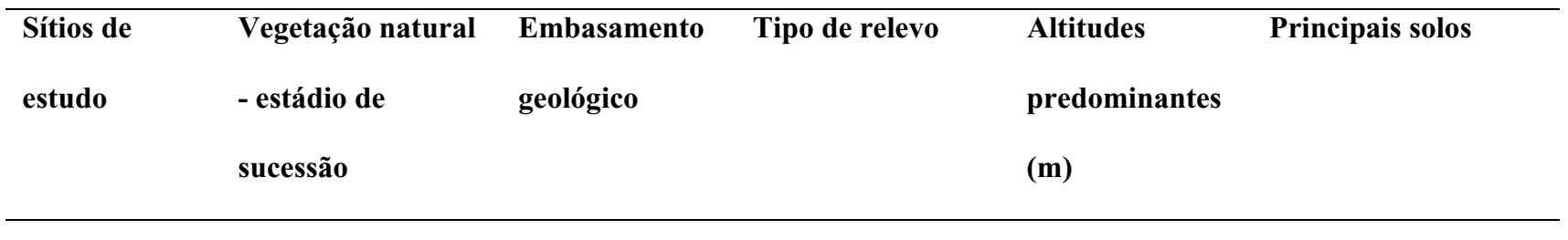

\begin{tabular}{|c|c|c|c|c|c|}
\hline Ferrovia 2 & Pioneiro/Inicial & Granitos & Morros/Morrotes & $900-950$ & Cambissolos háplicos \\
\hline A & Médio/Avançado & Granitos & Morros & $860-900$ & Cambissolos háplicos \\
\hline B & Médio/Avançado & Granitos & Morros & $900-950$ & Cambissolos háplicos \\
\hline $\mathrm{C}$ & Médio/Avançado & Granitos & Morrotes & $900-950$ & Cambissolos háplicos \\
\hline $\mathrm{D}$ & Médio/Avançado & Granitos & Morrotes & $900-950$ & Cambissolos háplicos \\
\hline Ruth & Médio/Avançado & Granitos & Morros & $900-950$ & $\begin{array}{l}\text { Latossolos vermelho- } \\
\text { amarelos }\end{array}$ \\
\hline Olaria & Médio/Avançado & Granitos & Morros & $860-900$ & Cambissolos háplicos \\
\hline Riacho & Médio/Avançado & Granitos & Morros/Morrotes & $860-900$ & Cambissolos háplicos \\
\hline Torres & $\begin{array}{l}\text { Médio/Avançado e } \\
\text { Avançado/Maduro }\end{array}$ & Migmatitos & Escarpas & $1000-1075$ & $\begin{array}{l}\text { Latossolos vermelho- } \\
\text { amarelos }\end{array}$ \\
\hline Ferrovia 1 & $\begin{array}{l}\text { Médio/Avançado e } \\
\text { Avançado/Maduro }\end{array}$ & Granitos & Morrotes & $950-1000$ & Cambissolos háplicos \\
\hline Grilos & $\begin{array}{l}\text { Médio/Avançado e } \\
\text { Avançado/Maduro }\end{array}$ & Granitos & Morros & $1000-1075$ & $\begin{array}{l}\text { Latossolos vermelho- } \\
\text { amarelos }\end{array}$ \\
\hline Quilombo & Avançado/Maduro & Granitos & Morros & $950-1000$ & Cambissolos háplicos \\
\hline Capelinha & Avançado/Maduro & Granitos & Morros & $950-1000$ & Cambissolos háplicos \\
\hline
\end{tabular}

http://www.biotaneotropica.org.br 


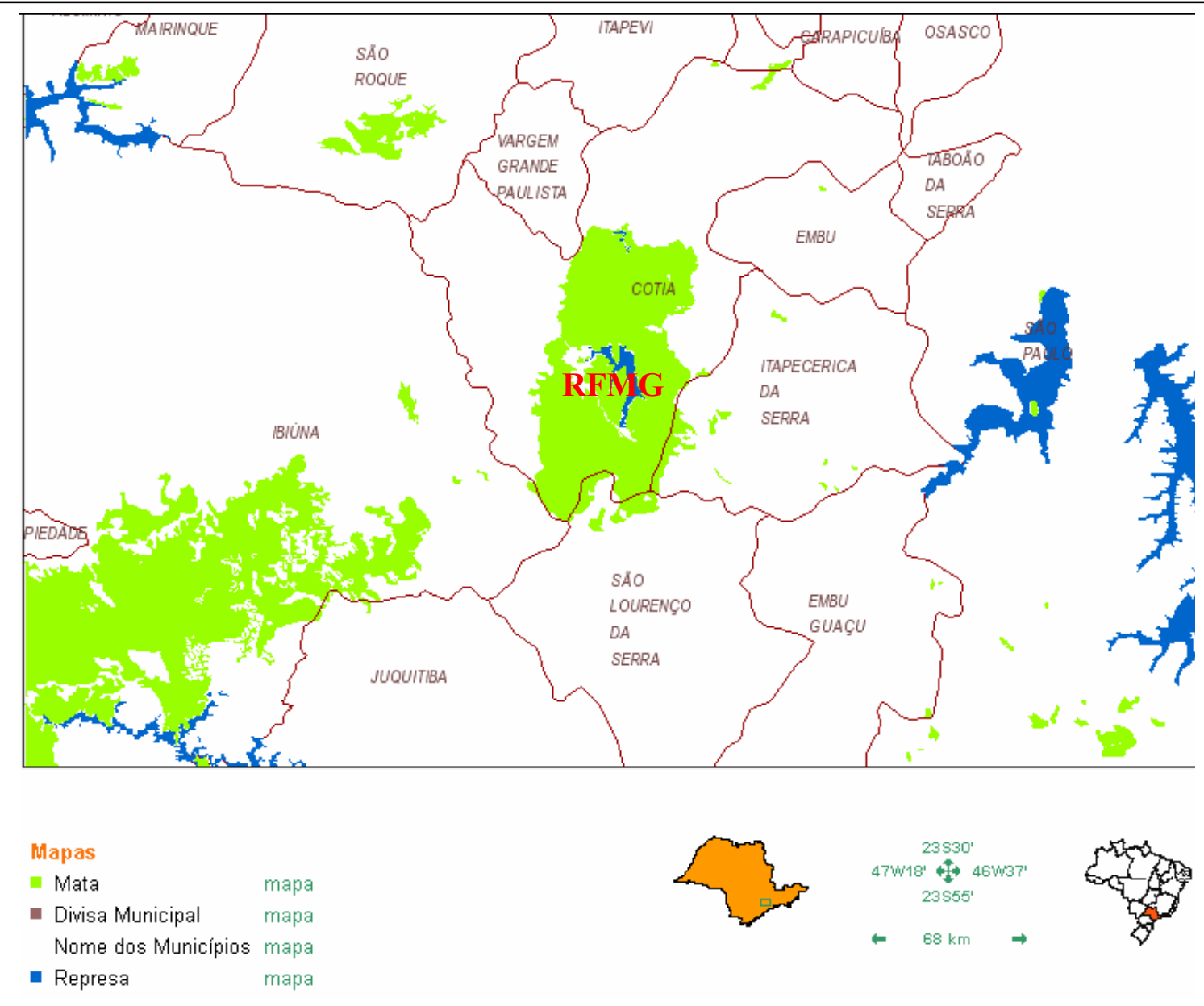

Figura 1. Municípios abrangidos pela RFMG e seu entorno. Fonte: Atlas Sinbiota (http://sinbiota.cria.org.br/atlas/), (C) 2001, Biota/Fapesp \& Centro de Referência em Informação Ambiental.

Figure 1. Municipalities around the Morro Grande Forest Reserve. Source: Atlas Sinbiota (http://sinbiota.cria.org.br/atlas/), (C) 2001, Biota/ Fapesp \& Centro de Referência em Informação Ambiental. 


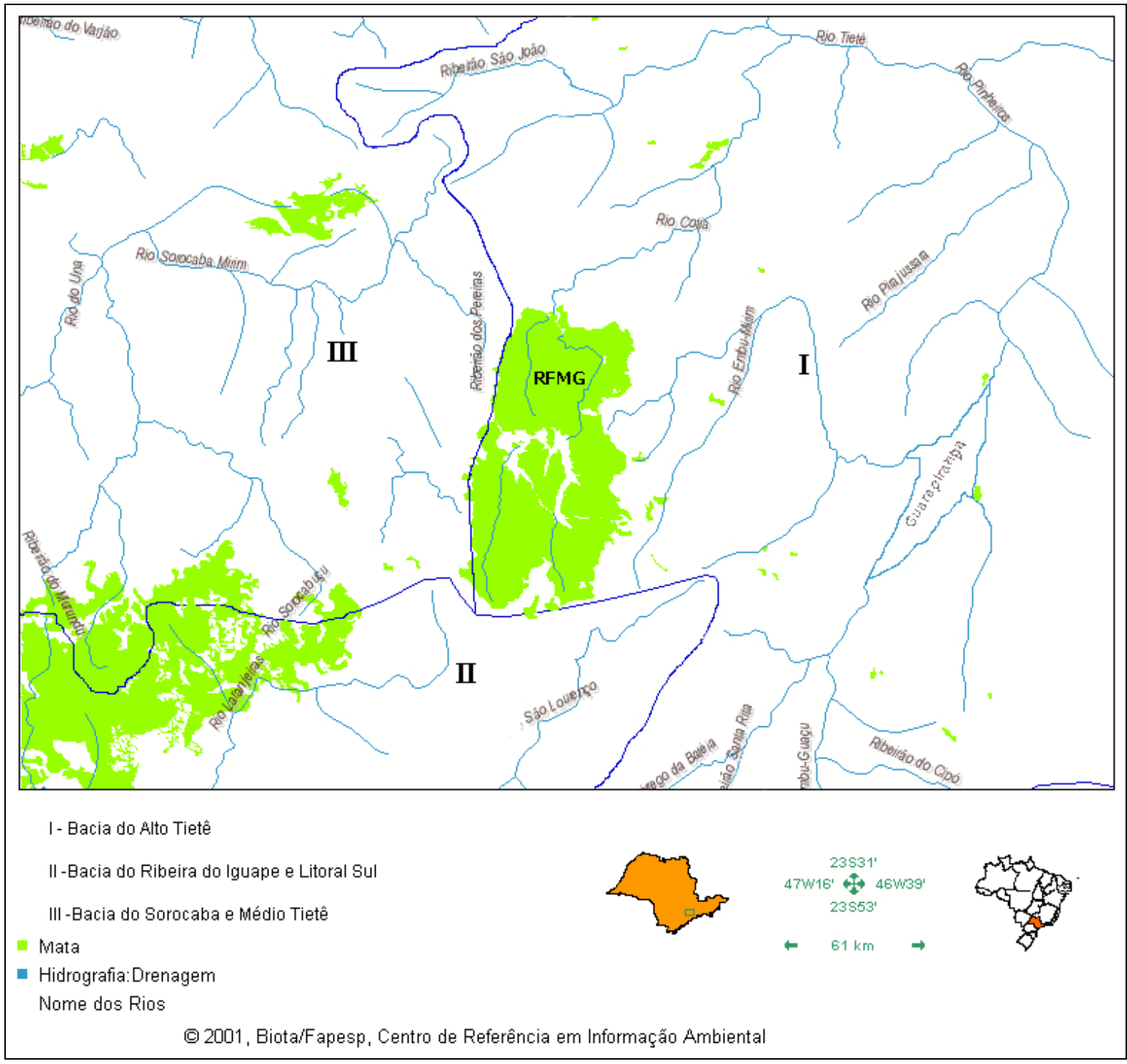

Figura 2. Bacias hidrográficas da RFMG e o seu entorno, sem escala. Fonte: Atlas Sinbiota (http://sinbiota.cria.org.br/atlas/), ( ) 2001, Biota/ Fapesp \& Centro de Referência em Informação Ambiental, modificado.

Figure 2. Watersheds from the Morro Grande Forest Reserve region (without scale). Source: Atlas Sinbiota (http://sinbiota.cria.org.br/atlas/), (c) 2001, Biota/Fapesp \& Centro de Referência em Informação Ambiental, modified. 


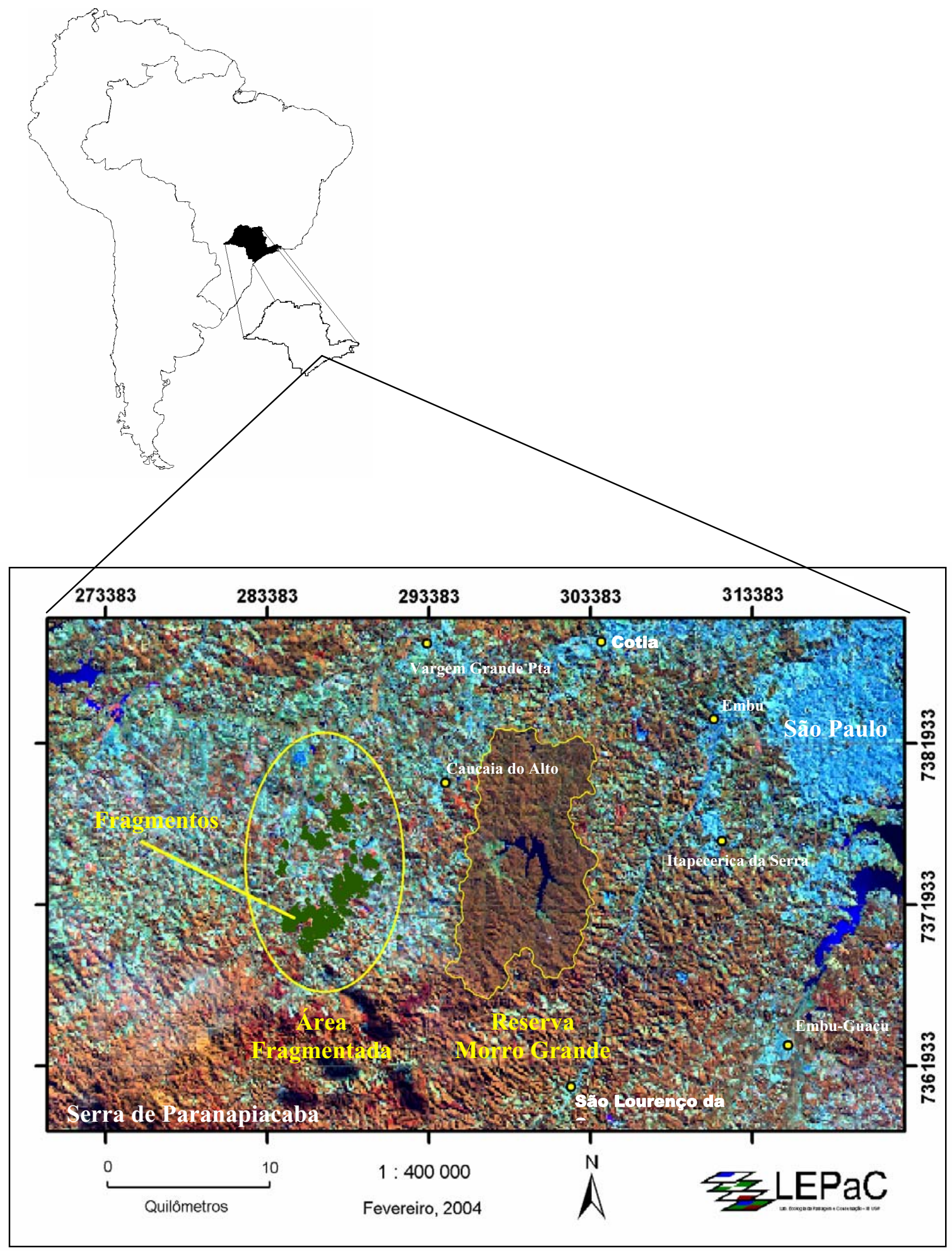

Figura 3. Imagem do satélite LANDSAT apresentando com a localização da Reserva Florestal do Morro Grande e da área fragmentada (a oeste da Reserva) onde foram feitos os estudos do Projeto Temático BIOTA-Caucaia (Fonte: Goulart 2004). Legenda de cores: em marrom avermelhado aparecem as florestas; em vermelho mais escuro, reflorestamentos; em azul claro, as áreas de solo exposto (e.g. agricultura) ou áreas construídas, como estradas e áreas urbanas (em particular, cidade de São Paulo a leste); em azul escuro, corpos d'água.

Figure 3. LANDSAT image showing the location of the Morro Grande Forest Reserve and the adjacent fragmented landscape (west of the Reserve) investigated by the BIOTA-Caucaia thematic project (Source: Goulart 2004). Legend: red/brown: forest; dark red: Eucalyptus spp. and Pinus spp. plantation; light blue: bare soils (e.g., agriculture), roads or urban areas (São Paulo city at the east side); dark blue: water

http://www.biotaneotropica.org.br 


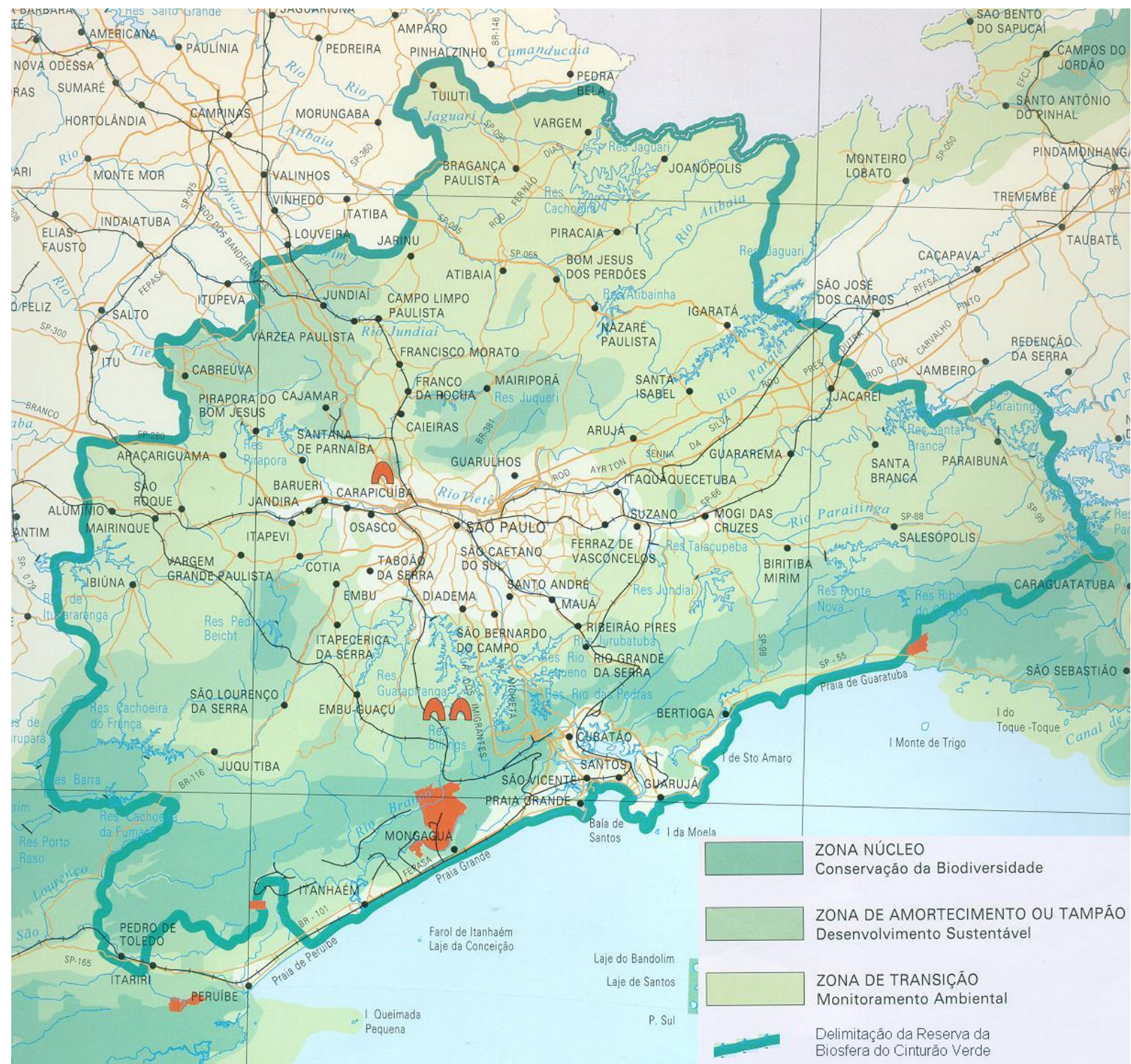

Figura 4. Mapa de zoneamento da Reserva da Biosfera do Cinturão Verde da Cidade de São Paulo. Fonte: http://www.iflorestsp.br/rbcv/index.html. Figure 4. Map of the São Paulo City's Green Belt Biosphere Reserve zones. Source: http://www.iflorestsp.br/rbcv/index.html. 
1962-1992

$1339 \mathrm{~mm}$

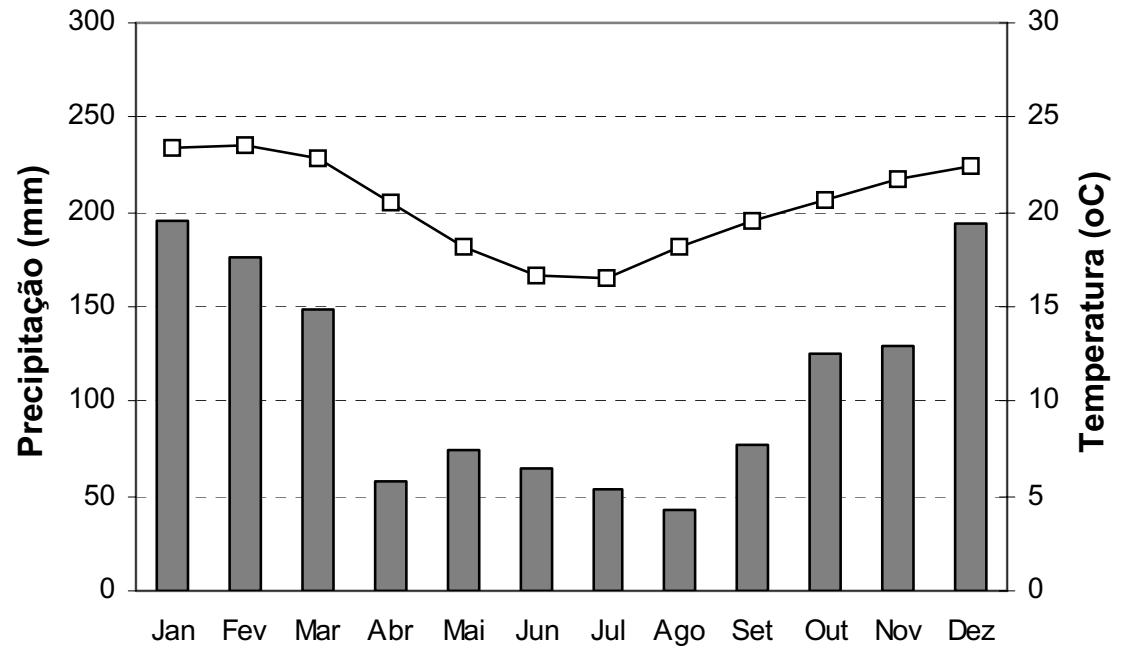

$\square$ Precipitação $\rightarrow$-Temperatura

Figura 5. Precipitação média mensal ( $\mathrm{mm}$ ) e temperatura média mensal $\left({ }^{\circ} \mathrm{C}\right)$ no período de $1962-1992$ para a região de Ibiúna, SP (471’ W e 2340’S, $850 \mathrm{~m}$ de altitude), distante cerca de $26 \mathrm{~km}$ da Reserva Florestal do Morro Grande (Fonte de dados: CIIAGRO - Instituto Agronômico de Campinas, SP, www.iac.sp.gov.br).

Figure 5. Month average precipitation ( $\mathrm{mm})$ and temperature $\left({ }^{\circ} \mathrm{C}\right)$ in the $1962-1992$ period obtained in Ibiúna, SP $\left(47^{\circ} 13^{\prime} W\right.$ and $23^{\circ} 40^{\prime} S$; altitude of $850 \mathrm{~m}$ ), $26 \mathrm{~km}$ distant from the Morro Grande Forest Reserve (Soure: CIIAGRO - Instituto Agronômico de Campinas, SP, www.iac.sp.gov.br).

http://www.biotaneotropica.org.br 


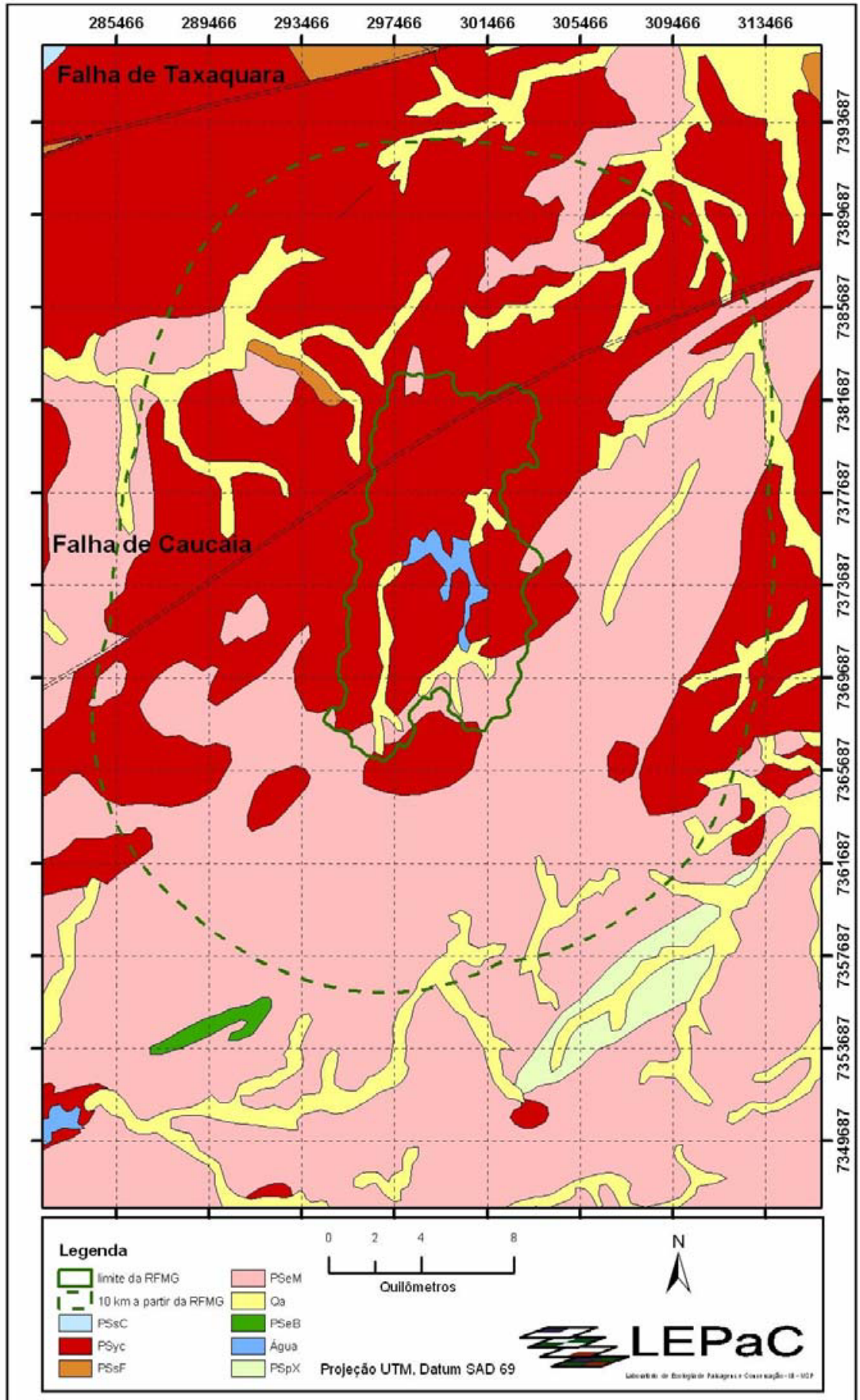

Figura 6. Mapa geológico da Reserva Florestal do Morro Grande e seu entorno. Fonte: Almeida et al. (1981). Ver tabela 3 para detalhamento da legenda.

Figure 6. Geological map of the Morro Grande Forest Reserve region. Source: Almeida et al. (1981). See Table 3 for legend details. 


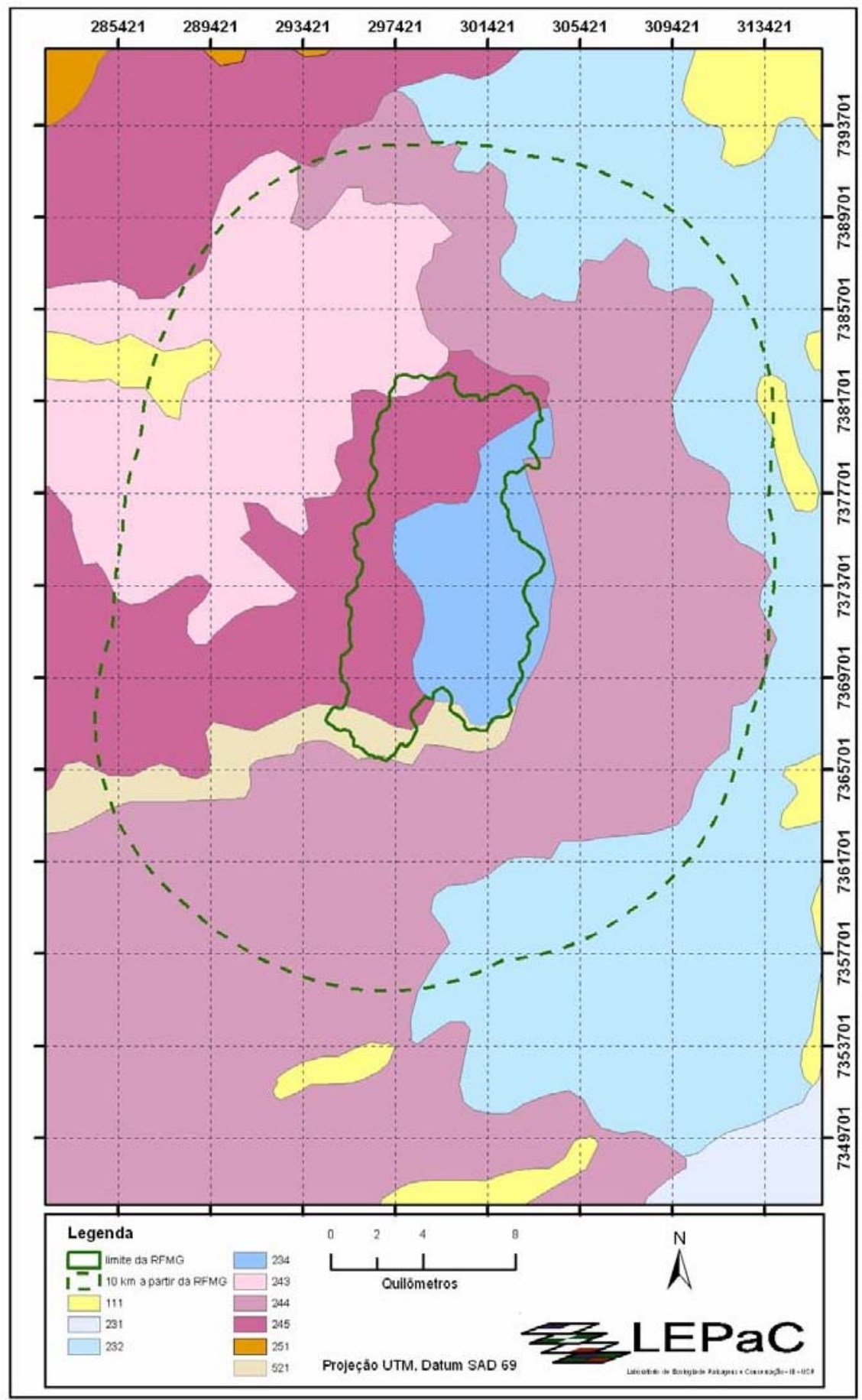

Figura 7. Mapa geomorfológico da Reserva Florestal do Morro Grande e seu entorno. Fonte: Ponçano et al. (1981). Ver tabela 4 para detalhamento da legenda.

Figure 7. Geomorphological map of the Morro Grande Forest Reserve region. Source: Ponçano et al. (1981). See Table 4 for legend details 


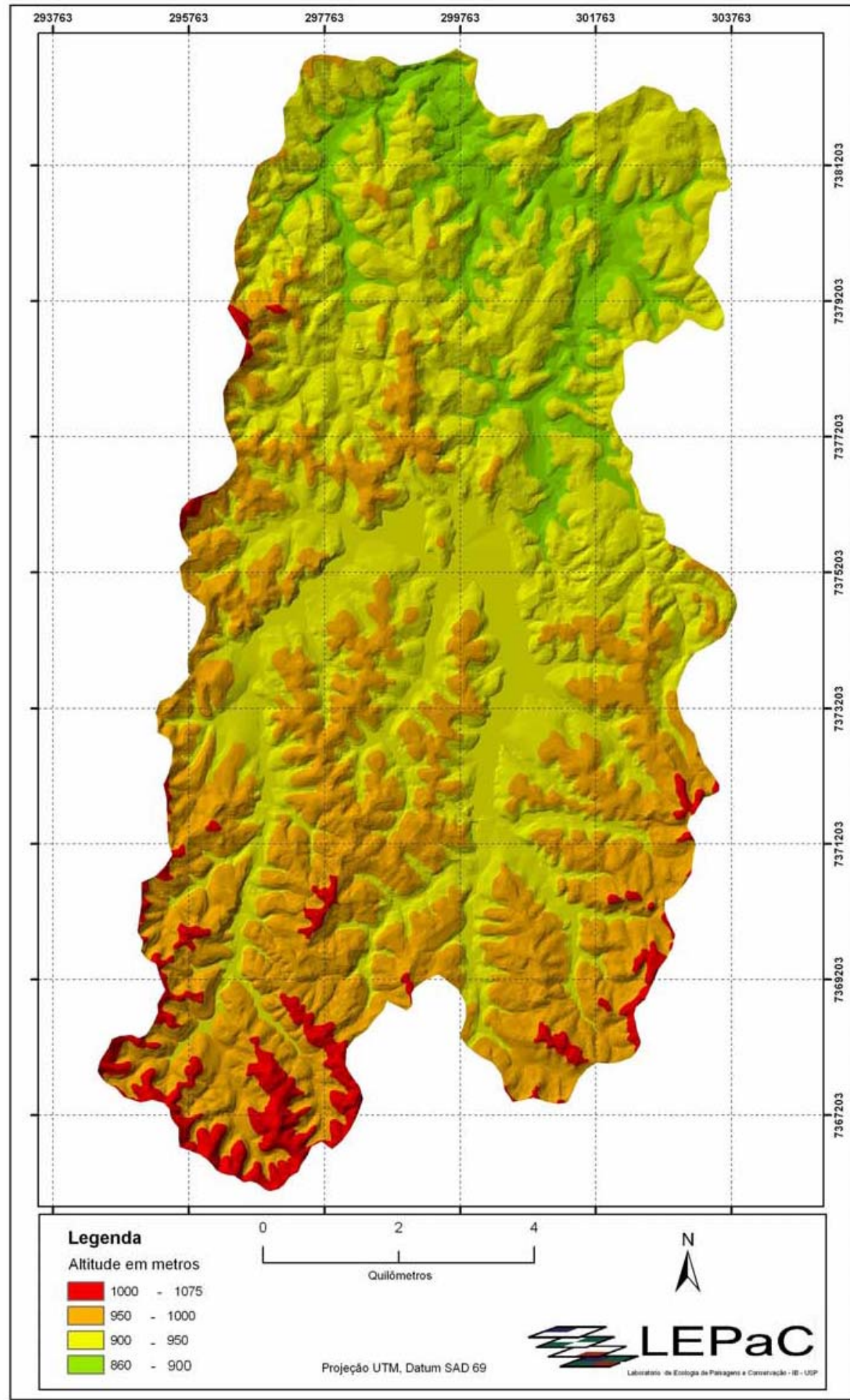

Figura 8. Mapa hipsométrico da Reserva Florestal do Morro Grande.

Figure 8. Hipsometric map of the Morro Grande Forest Reserve. 


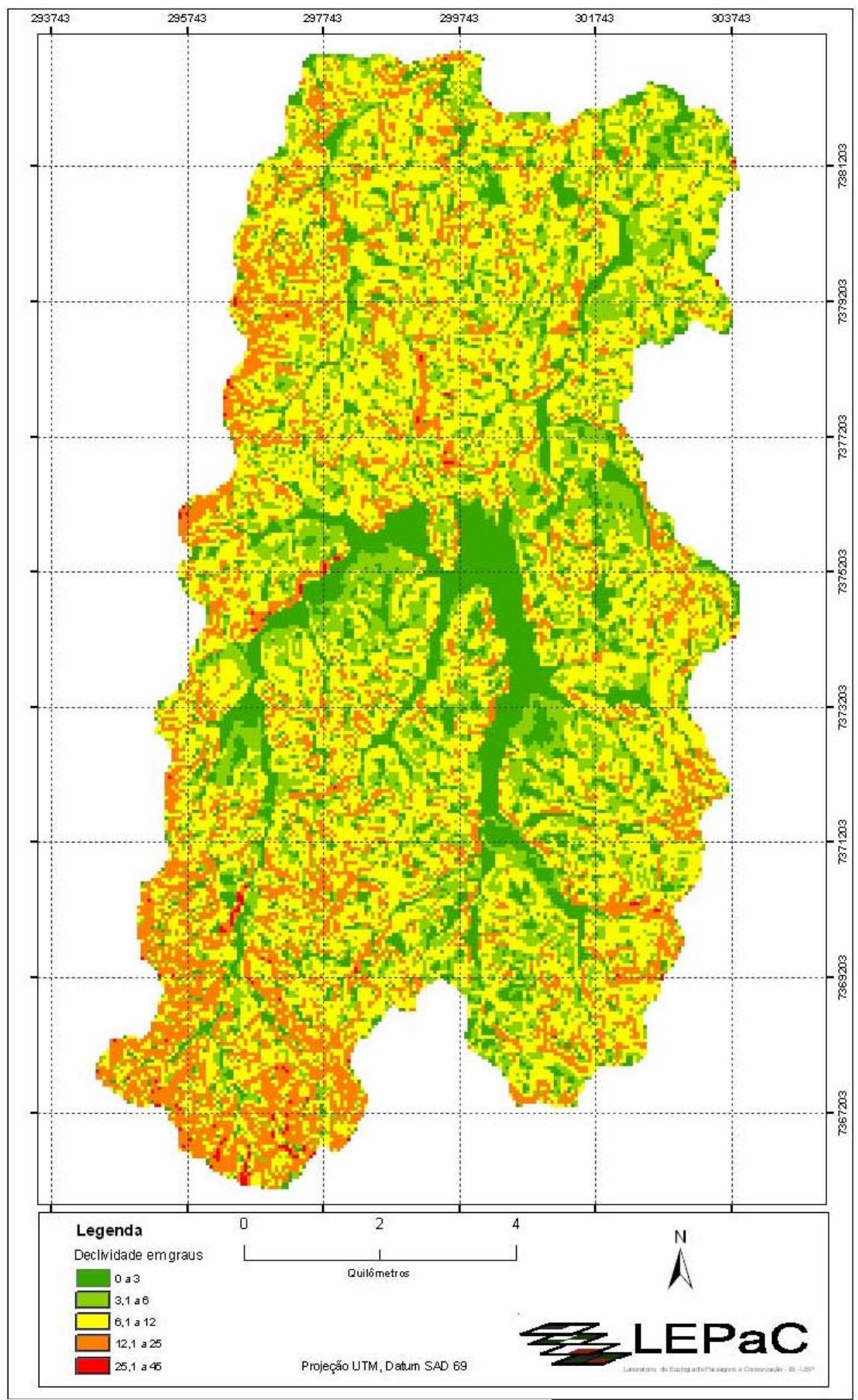

Figura 9. Mapa de declividade da Reserva Florestal do Morro Grande.

Figure 9. Slope map of the Morro Grande Forest Reserve. 


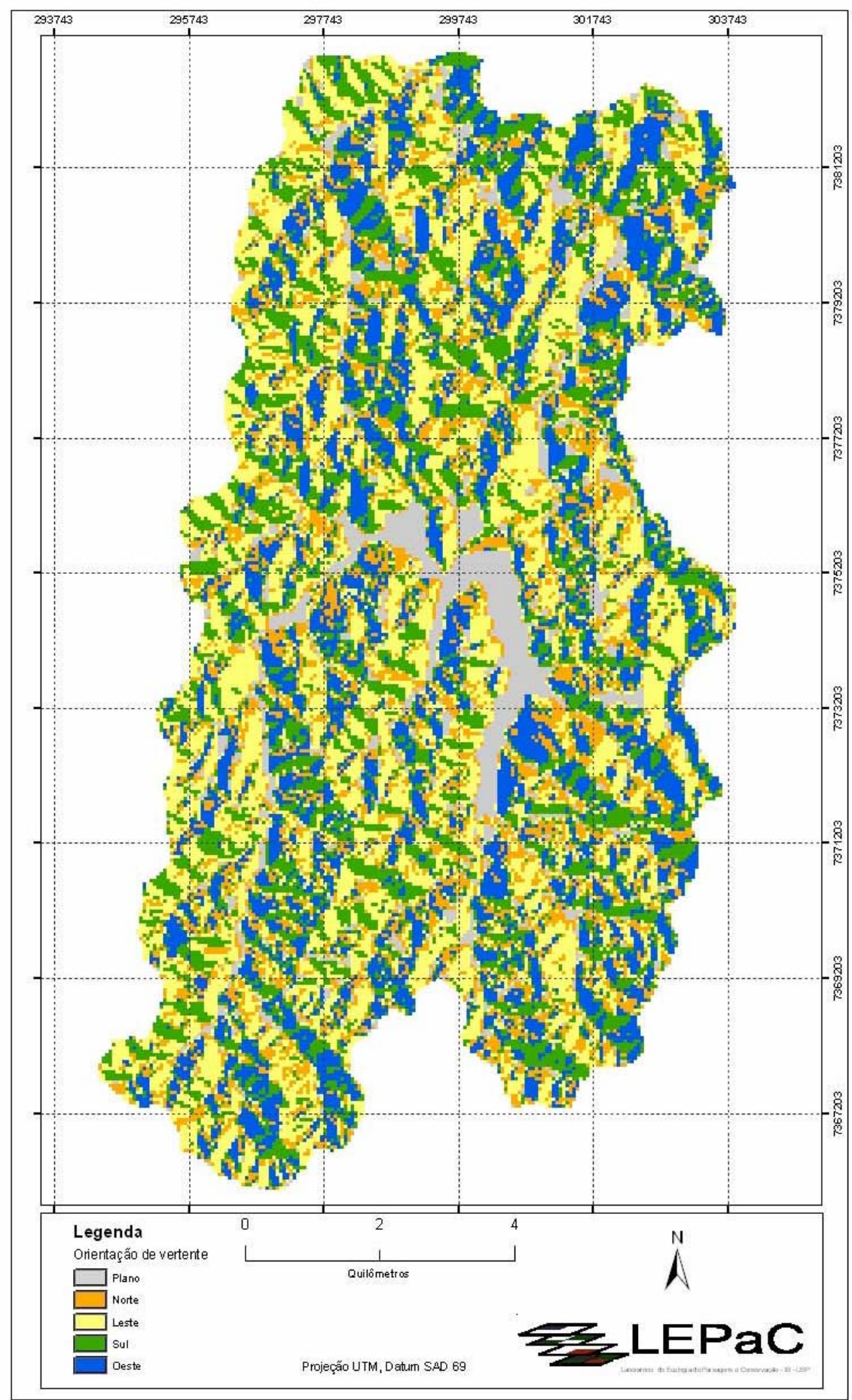

Figura 10. Mapa de orientação das vertentes da Reserva Florestal do Morro Grande.

Figure 10. Aspect map of the Morro Grande Forest Reserve. 


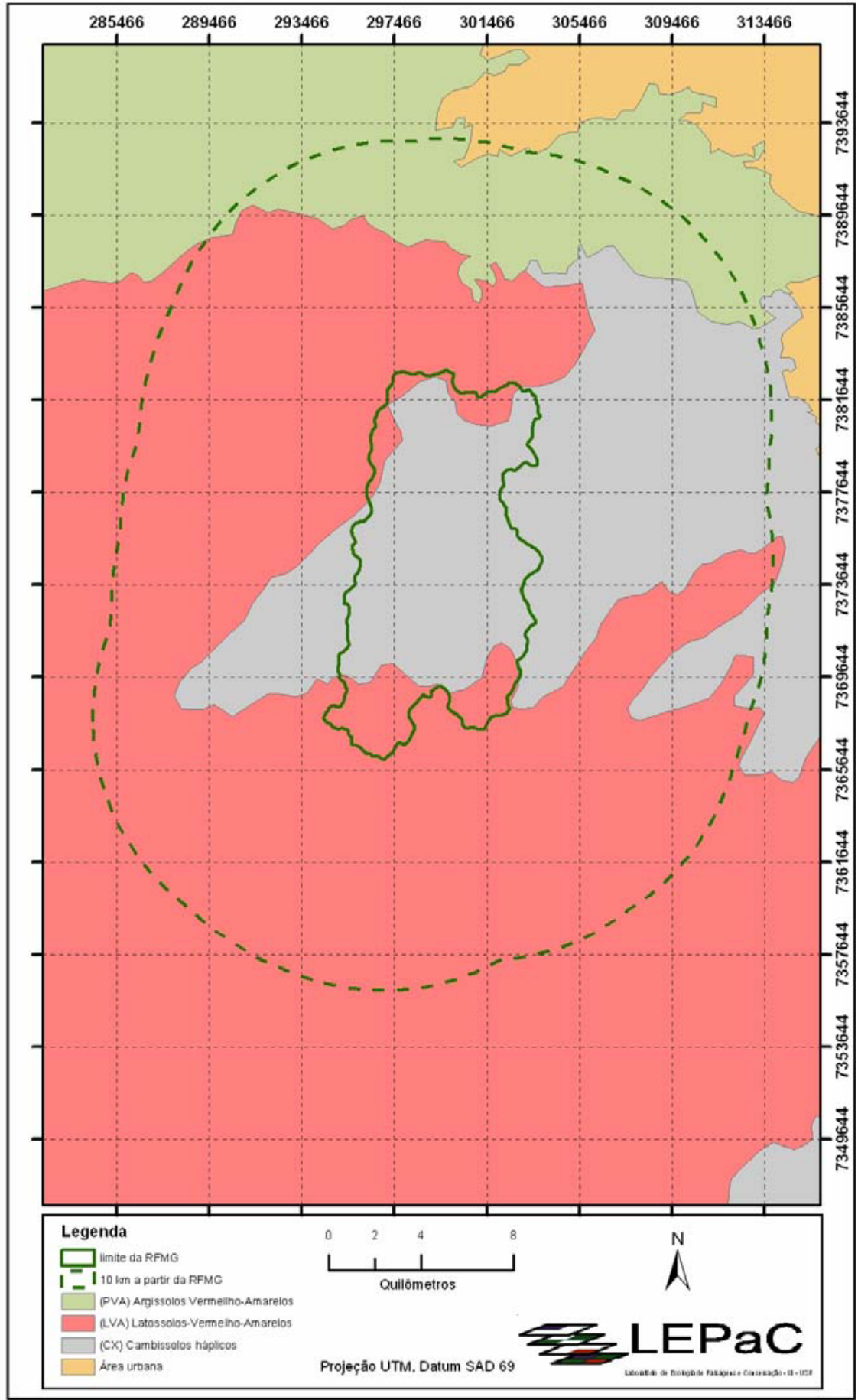

Figura 11. Mapa pedológico da Reserva Florestal do Morro Grande e seu entorno. Fonte: Oliveira et al. (1999). Ver texto para detalhamento da legenda.

Figure 11. Pedological map of the Morro Grande Forest Reserve region. Source: Oliveira et al. (1999). See text for legend details. 


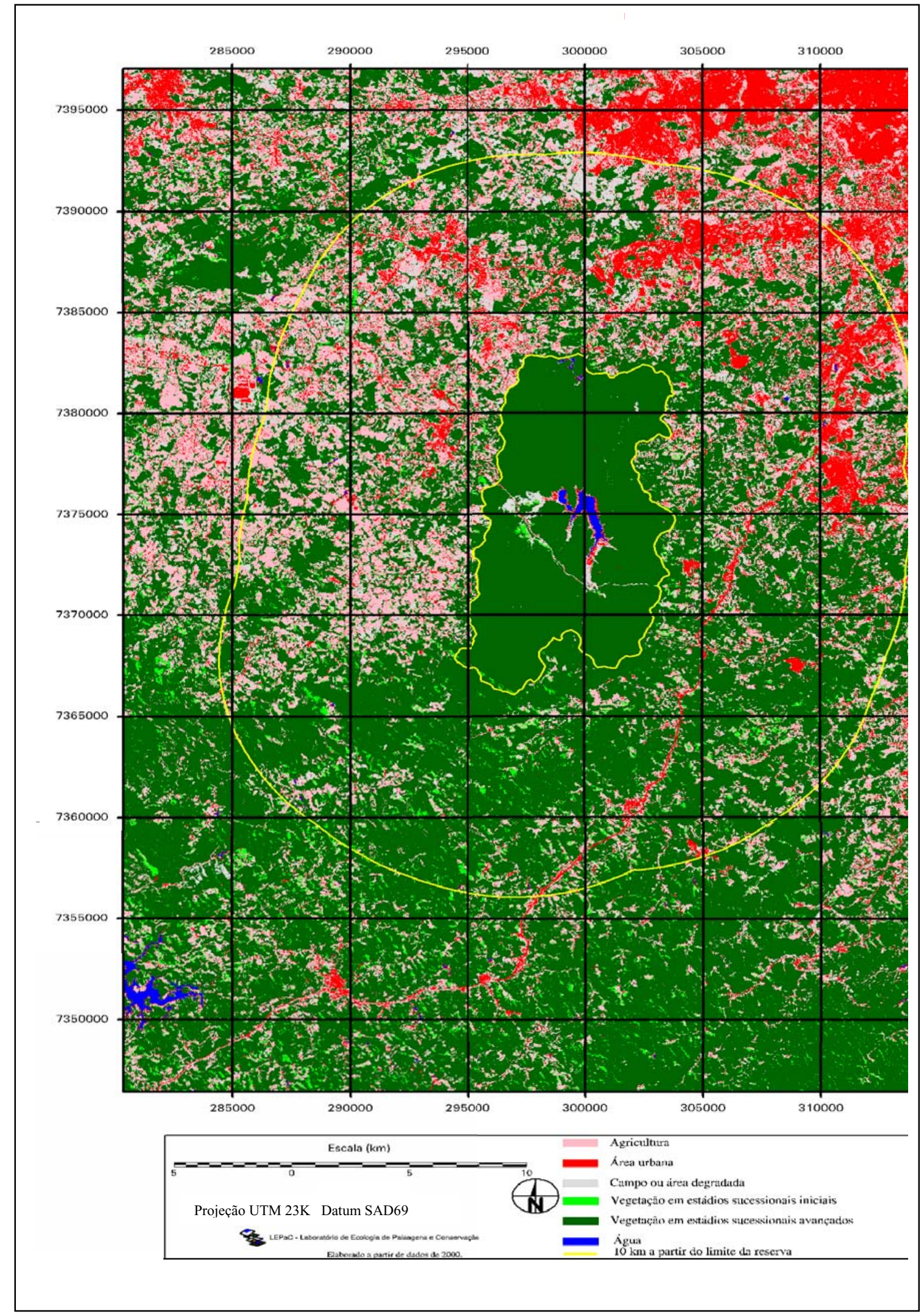

Figura 12. Mapa de uso e cobertura do território da Reserva Florestal do Morro Grande e entorno obtido a partir da classificação supervisionada de duas imagens Landsat ETM+ (Abril/2000).

Figure 12. Land use and land cover map from the Morro Grande Forest Reserve region obtained from supervised classification of a LANDSAT ETM+ images (April/2000). 


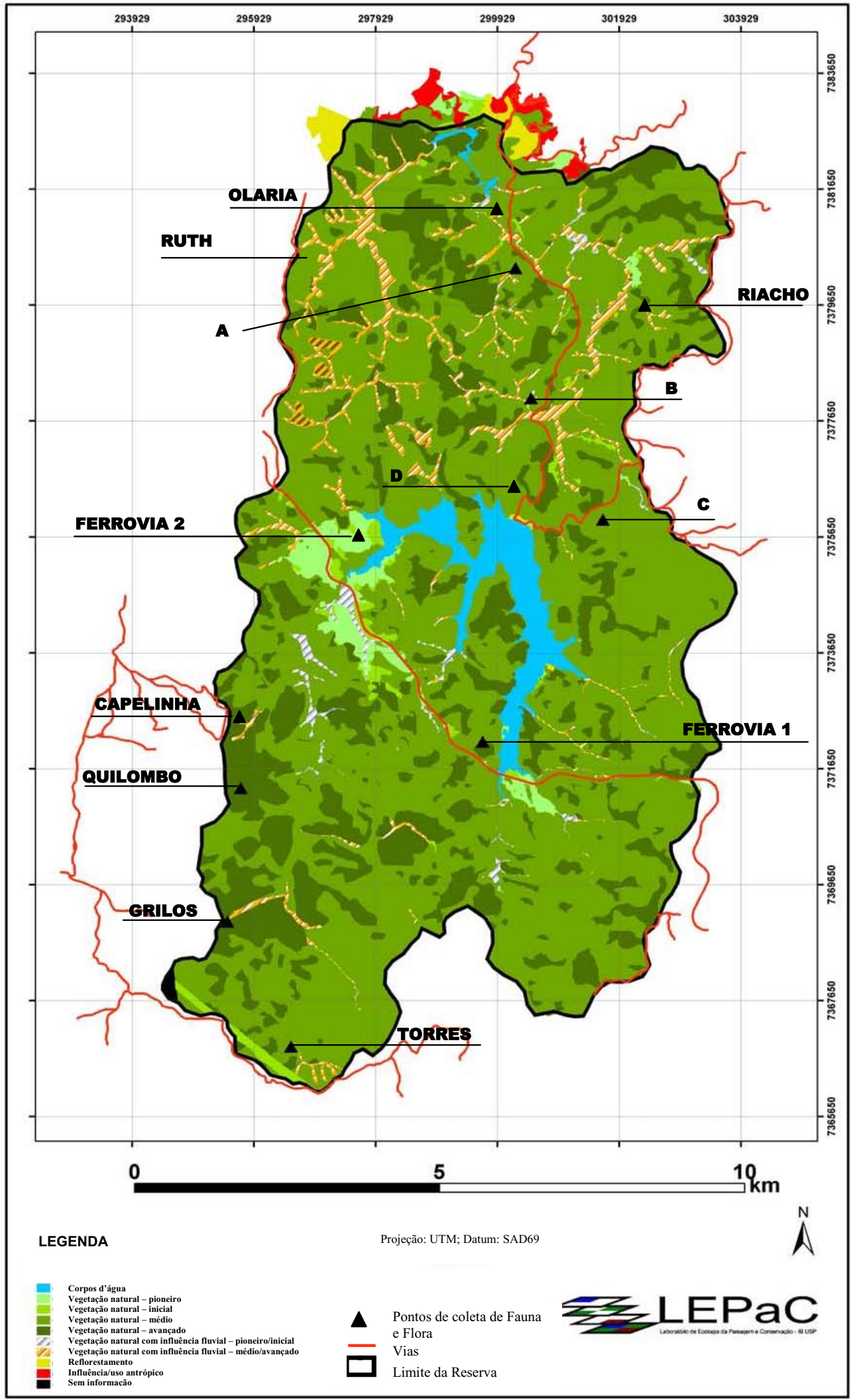

Figura 13. Mapa de uso e cobertura do território referente à área da RFMG nos anos de 1994 e 1995, obtido por interpretação visual de pares aerofotogramétricos na escala de 1/25.000. Ver Tabela 5 para detalhamento da legenda.

Figure 13. Land use and land cover map from the interior of the Morro Grande Forest Reserve (1994-1995) obtained from aerial photographs interpretation (1/25.000). See Table 5 for legend details. 